DOI: 10.32089/WBH.PHW.2020.1(271).0006

orcid.org/0000-0002-5894-0930

JERZY KIRSZAK

(Oddziałowe Biuro Badań Historycznych IPN we Wrocławiu;

Wojskowe Biuro Historyczne im. gen. broni Kazimierza Sosnkowskiego)

\title{
Cóż będzie dalej? Nieznany list gen. broni Kazimierza Sosnkowskiego z roku 1945 o sytuacji międzynarodowej i perspektywach sprawy polskiej
}

W bogatej spuściźnie gen. broni Kazimierza Sosnkowskiego przechowywanej w archiwum Instytutu Józefa Piłsudskiego w Ameryce w Nowym Jorku (IJPA) natrafiłem w 2003 r. na odpis bardzo ciekawego, napisanego piękną polszczyzną, niezwykle obszernego listu generała. Adresatem był płk dypl. Franciszek Demel, przez wiele lat oficer z najbliższego otoczenia gen. Sosnkowskiego, bezwzględnie oddany służbie i swemu przełożonemu. Obu łączyła przyjaźń, choć pozornie mogłoby się wydawać, że jednostronna, bowiem generał nieraz bywał wobec pułkownika szorstki, a zawsze bardzo wymagający. Mimo że „zjedli ze sobą beczkę soli” (jak przeczytamy niżej), nie mówili sobie po imieniu. Można by między nimi dopatrywać się pewnych analogii do relacji Komendant Piłsudski - Szef Sosnkowski, wszelako rola i oddziaływanie Demela na Sosnkowskiego nie były tej miary i wagi, co rola Sosnkowskiego przy Józefie Piłsudskim, ponieważ - jak celnie zauważył świadek epoki - Sosnkowski był „nieodłącznym z Piłsudskim współtwórcą i współwykonawcą"', zaś Demel tylko szefem sztabu i czasem doradcą. Co ciekawe, Demela z Sosnkowskim łączyła też symbolicznie data urodzin - obaj obchodzili je w tym samym dniu ale pułkownik był o 11 lat młodszy. Po $1945 \mathrm{r}$. kontakty generała z pułkownikiem rozluźniły się na ponad dwie dekady, by w połowie lat sześćdziesiątych odżyć korespondencyjnie na nowo.

${ }^{1}$ M. Sokolnicki, Przedmowa [w:] Kazimierz Sosnkowski o Józefie Piłsudskim, oprac. S. Biegański, Londyn 1961, s. 3. 
Do rangi symbolu ich wzajemnych relacji urasta zaś fakt, że spośród tysięcy listów które w swoim niezwykle długo aktywnym życiu napisał Sosnkowski, ostatni z 8 października 1969 r. był właśnie do Demela. Trzy dni później generał już nie żył.

Pominę w tym miejscu prezentację autora listu, na którego temat dysponujemy całkiem pokaźną literaturą, choć wciąż brakuje rzetelnej biografii Sosnkowskiego ${ }^{2}$. Inaczej jest $\mathrm{z}$ adresatem listu. Pułkownik dyplomowany Franciszek Demel, ps. „Heczka”, „Stary” - żołnierz I Brygady Legionów, oficer WP, szef sztabu Komendy Głównej Związku Walki Zbrojnej (KG ZWZ), szef Oddziału Operacyjnego Sztabu Naczelnego Wodza, dowódca 4 Wołyńskiej Brygady Piechoty - oprócz kilku notek biograficznych nie ma dotąd żadnej biografii ${ }^{3}$. Dlatego warto też - dla głębszego zrozumienia stopnia zażyłości między generałem a pułkownikiem - szerzej przedstawić jego sylwetkę.

Franciszek Demel urodził się w Brodach 19 listopada 1896 r., tam też uczęszczał do gimnazjum klasycznego (maturę zdał w 1915 r. w Wadowicach). Od 22 sierpnia 1914 r. służył w oddziale Józefa Piłsudskiego - był strzelcem w 3 kompanii VI batalionu późniejszej I Brygady Legionów. W 1915 r. awansował na kaprala, a w 1916 r. na sierżanta. Po kryzysie

${ }^{2}$ Kazimierz Sosnkowski doczekał się dotąd pięciu monografii: S. Babiński, Kazimierz Sosnkowski, myśl-praca-walka, Londyn 1988; M. Pestkowska, Kazimierz Sosnkowski, Wrocław 1995; I. Wojewódzki, Kazimierz Sosnkowski podczas II wojny światowej. Książę niezłomny czy Hamlet w mundurze?, Warszawa 2009; L. Wyszczelski, Generał Kazimierz Sosnkowski, Warszawa 2010; J. Kirszak, Generał Kazimierz Sosnkowski 1885-1969, Warszawa 2012. Przy czym żadna z nich nie jest całościową biografią naukową generała. Pionierskie opracowanie Stanisława Babińskiego - „przyjaciela ideowego z młodego pokolenia”, jak mówił o nim Sosnkowski - jest po trosze antologią tekstów poświęconych generałowi i edycją źródeł. Prace Marii Pestkowskiej i moja mają charakter popularny, Ireneusz Wojewódzki skupił się głównie na II wojnie światowej, zaś Lech Wyszczelski nie wykorzystał elementarnych źródeł, popełnił szereg błędów i „zapożyczeń”, tym samym jego książka nie może pretendować do miana naukowej. Szerzej zob. J. Kirszak, Nowa biografia generała Kazimierza Sosnkowskiego, „Przegląd Historyczno-Wojskowy” (dalej: PHW) 2011, nr 1 (234), s. 163-179; idem, Profesorowi Lechowi Wyszczelskiemu w odpowiedzi, PHW 2011, nr 2 (235), s. 207-222; D. Koreś, Generał Sosnkowski według Wyszczelskiego, „Biuletyn Instytutu Pamięci Narodowej" 2011, nr 1/2, s. 180-185. Recenzje te są dostępne on-line.

${ }^{3}$ Krótkie notki biograficzne (z bibliografią) zob. m.in.: M. Ney-Krwawicz, Biuro Generała Sosnkowskiego. Komenda Główna Związku Walki Zbrojnej we Francji listopad 1939 - czerwiec 1940, Warszawa 1996, s. 98, 99; J. Kirszak, Wybrani oficerowie Armii „Karpaty” i ich późniejsze losy w II wojnie światowej [w:] Dzieje Podkarpacia, t. 4, pod red. J. Garncarskiego, Krosno 2000, s. 219. Również mego autorstwa jest bodaj najpełniejszy dotąd szkic biograficzny Demela - zob. J. Kirszak, „Karpacka czwórka” o sobie. Generat broni Kazimierz Sosnkowski, podpułkownik dypl. Franciszek Demel, inżynier Rajmund Scholz i kapral Alfred Codello - uczestnicy przejścia przez Karpaty na Węgry we wrześniu-październiku 1939 roku - wświetle własnych relacji [w:] Podkarpacki wrzesień. Polityczne i wojskowe aspekty wojny obronnej Polski 1939 r. na Podkarpaciu, red. A. Olejko i P. Korzeniowski, Rzeszów 2010, s. $155-172$. 
przysięgowym Legionów wcielono go do armii austriackiej i wysłano na front włoski. W maju 1918 r. został zwolniony i rozpoczął studia medyczne na Uniwersytecie Jagiellońskim.

1 listopada 1918 r. wstąpił w Krakowie do formującego się WP, początkowo służył w 5 pp Leg. Od lutego 1919 r. dowodził 11 kompanią 32 pp, początkowo „w kraju”, a od stycznia 1920 r. na froncie. Podporucznikiem został w marcu 1919 r., porucznikiem w lipcu 1920 r., kapitanem w lutym 1921 r. W latach 1923-1925 studiował w Wyższej Szkole Wojennej (IV promocja). Następnie był referentem operacyjnym IX Dowództwa Okręgu Korpusu, oficerem sztabu inspektora armii gen. dyw. Józefa Rybaka (1926-1929), kierownikiem Samodzielnego Referatu Operacyjnego Oddziału III Sztabu Głównego (1929-1930), kierownikiem Referatu „Rosja”, później szefem Wydziału Studiów Oddziału II Sztabu Głównego (SG) w latach 1930-1933. Następnie (1933-1935) dowodził batalionem w 30 Pułku Strzelców Kaniowskich. Wcześniej jeszcze, w styczniu 1929 r., awansował do stopnia majora dyplomowanego.

W grudniu 1935 r. został oficerem sztabu inspektora armii gen. dyw. Sosnkowskiego. Od tego momentu datuje się ich niemal dziesięcioletnia ścisła współpraca wojskowa. W styczniu 1936 r. awansował na podpułkownika. Jego bezpośredni przełożony ppłk dypl. Alfred Krajewski w Rocznej Liście Kwalifikacyjnej za 1936 r. pisał o Demelu: „Umysł bystry, a jednocześnie refleksyjny i analityczny. Zdolny i inteligentny, wybitnie pracowity, bardzo dokładny i sumienny. Zdyscyplinowany i bardzo lojalny; koleżeński i trochę rubaszny. Bardzo wytrzymały na trudy"4.

1 listopada 1938 r. został I oficerem sztabu (czyli na wypadek wojny szefem sztabu armii) gen. broni Sosnkowskiego. W Rocznej Liście Kwalifikacyjnej za rok 1938 inspektor armii tak go opiniował: „Oddany służbie całą duszą; zamiłowany i dumny żołnierz. Prawy, porządny charakter. Temperament spokojny, opanowany, refleksyjny. Sumienny pracownik; wnikliwy, systematyczny, dokładny”. W podsumowaniu i określeniu przydatności, gen. Sosnkowski konkludował: „Bardzo dobry oficer. Nadaje się na Szefa Sztabu Armii, szefa oddziału w Sztabie Głównym, dowódcę pułku piechoty"s.

We wrześniu 1939 r. był oficerem do zleceń gen. Sosnkowskiego i dzielił los swego przełożonego od Warszawy po ostatnie walki pod Lwowem i dalej na szlaku do Paryża. W sporządzonym w 1940 r. wniosku na odznaczenie Demela orderem Virtuti Militari V kl., gen. Sosnkowski pisał: „Jako oficer mego sztabu zgłosił się dobrowolnie na ochotnika, by towarzyszyć mi w locie z oblężonego Lwowa do grupy wojsk odciętych pod Przemyślem.

\footnotetext{
${ }^{4}$ Instytut Polski i Muzeum im. gen. Sikorskiego w Londynie (dalej: IPMS), płk dypl. Franciszek Demel, sygn. KOL.193/4, Roczna Lista Kwalifikacyjna 1936.

${ }^{5}$ Ibidem, Roczna Lista Kwalifikacyjna 1938.
} 
W najcięższych sytuacjach w toku bojów pod Przemyślem, Sądową Wisznią, Jaworowem, Janowem i Lwowem Płk Demel zachowywał spokój i zimną krew, wywiązując się bardzo sprawnie z powierzonych mu zadań. Był mi nieodłącznym towarzyszem biorąc osobisty udział w ciężkich walkach toczonych dniem i nocą pod silnym ogniem lotnictwa i artylerii niemieckiej, nierzadko w czołowych liniach bojowych. Gdy ostatnia krwawa próba zamierzonej odsieczy wskutek szczupłości sił pozostałej garści piechoty spełzła na niczym u bram Lwowa, Płk Demel po poddaniu się tego miasta towarzyszył mi wiernie $\mathrm{w}$ wędrówce poprzez armie bolszewickie ku granicy węgierskiej"6. (Po weryfikacji płk Demel za wrzesień 1939 r. nie otrzymał Virtuti Militari, tylko Krzyż Walecznych).

Po dramatycznym przejściu przez Gorgany na Węgry udał się z gen. Sosnkowskim do Paryża, gdzie dojechali 11 października 1939 r. Od listopada był zastępcą szefa sztabu i Kierownikiem Okupacji Sowieckiej, a od stycznia 1940 r. szefem sztabu KG ZWZ. Używał pseudonimu „Heczka” (od nazwy granicznej góry, na której 4 października pożegnali się z Polską, przechodząc na Węgry). 3 maja 1940 r. awansował do stopnia pułkownika. Należał do grupy 10 oficerów - wraz z generałami Władysławem Sikorskim i Sosnkowskim - podjętych przez łódź latającą wysłaną przez premiera Winstona Churchilla 21 czerwca $1940 \mathrm{r}$.

W Wielkiej Brytanii był m.in. zastępcą szefa Oddziału VI (Specjalnego) Sztabu Naczelnego Wodza (NW). Po zwolnieniu gen. Sosnkowskiego z funkcji Komendanta Głównego ZWZ przez NW gen. Sikorskiego (25 lipca 1941 r.) dymisje objęły również oficerów z najbliższego otoczenia "Szefa”. We wrześniu 1941 r. płk Demel został odwołany z Oddziału VI i przeniesiony do 7 Brygady Kadrowej Strzelców na zastępcę dowódcy 20 batalionu, zaś w kwietniu 1943 r. w ogóle przeniesiony w stan nieczynny. W lipcu 1943 r. wrócił do służby powołany przez nowego NW gen. Sosnkowskiego na szefa Oddziału III Operacyjnego Sztabu NW. Na tym stanowisku utrzymywał niemal codzienny kontakt z Naczelnym Wodzem, uczestniczył w inspekcjach wojska, m.in. trzykrotnie podróżował z gen. Sosnkowskim do 2 Korpusu. Od listopada 1944 r. był szefem Oddziału Wyszkolenia Sztabu NW, a od stycznia 1945 r. pozostawał w dyspozycji dowódcy 2 Korpusu. Od 12 kwietnia do listopada 1945 r. dowodził 4 Wołyńską Brygadą Piechoty, nowo sformowaną „brakującą” trzecią brygadą 5 Kresowej Dywizji Piechoty (KDP) - m.in. w bitwie o Bolonię. Następnie został szefem Biura Planowania szefa Sztabu 2 Korpusu z siedzibą w Ankonie. Kierowane przez niego Biuro było faktycznie bazą wywiadowczą 2 Korpusu. W latach 1946-1949 był kierownikiem tzw. Komórki płk. Demela, która działała w Brukseli

\footnotetext{
${ }^{6}$ Biblioteka Zakładu Narodowego im. Ossolińskich (dalej: BZNiO), Papiery Kazimierza Sosnkowskiego, rkps 16508, Wniosek na odznaczenie Krzyżem Virtuti Militari, kl. V za wojnę polsko-niemiecką rok 1939, b.m., b.d., k. 69 .
} 
zakonspirowana w specjalnie do tego celu utworzonym warsztacie samochodowym i była sekcją wywiadu wojskowego gen. Władysława Andersa. Używał wówczas pseudonimu „Stary”. Niestety, działalność Komórki płk. Demela została rozpracowana przez Urząd Bezpieczeństwa, co spowodowało liczne aresztowania wśród osób współpracujących z Komórką7. Po jej rozwiązaniu przeniósł się do Londynu i włączył do prac zakonspirowanego Zawiązku Sztabu Głównego (ZSG), w zespole gen. bryg. Kazimierza Wiśniowskiego. Zespół ten śledził rozwój wiedzy militarnej na świecie i przygotowywał do ewentualnego odtworzenia Polskich Sił Zbrojnych (PSZ) na emigracji. Demel był odpowiedzialny za zagadnienia wojny psychologicznej oraz rozpracowania działań wojska w kraju. Ostatecznie ZSG przestał istnieć w 1955 r. W następnych latach Demel pracował fizycznie na utrzymanie m.in. w londyńskiej restauracji Lucullus. Zmarł 19 września 1976 r.

Kazimierz Sosnkowski lubił pisać listy i robił to po mistrzowsku. Pisał je przeważnie w nocy po dniu wytężonej pracy. Słusznie zauważył znawca literackich osiągnięć Sosnkowskiego, pisząc że „łatwo dostrzegalnymi cechami listów, podobnie jak i innych tekstów generała, są m.in. rzeczowość, dokładność, ścisłość, jasność myśli, precyzja wywodu i kultura wysłowienia"». Trudno powiedzieć, ile ich napisał. Wedle mego szacunku przez ponad 60 lat swego dorosłego życia mogło to być nawet kilka tysięcy, wśród których zdarzały się obszerne epistoły. Przykładem może być edytowany poniżej list o niespotykanej raczej objętości, liczącej prawie 22 strony maszynopisu! Powstał on na pustkowiu kanadyjskim - miejscu czasowego pobytu rodziny Sosnkowskich - i nosi datę 6 sierpnia 1945 r. Czy było to przypadkowe nawiązanie do rocznicy drogiej sercu każdego weterana I Brygady Legionów, w której szeregach ponad trzy dekady wcześniej nadawca i adresat rozpoczęli jawną walkę o niepodległość Polski? Nie wiadomo. W każdym razie w liście nie ma żadnego odwołania do tej symboliki.

Epistoła ta była odpowiedzią na list pułkownika z 2 Korpusu we Włoszech, którego nie odnalazłem w spuściźnie Sosnkowskiego. Pierwotnie chciałem opublikować oba dokumenty równolegle. Niestety, poszukiwania listu Demela w formie kopii/odpisu w jego kolekcjach rozproszonych w trzech archiwach polskich instytucji w Londynie (Instytut Józefa Piłsudskiego, Instytut Polski i Muzeum im. gen. Sikorskiego, Studium Polski Podziemnej)

${ }^{7}$ Archiwum Instytutu Pamięci Narodowej w Warszawie, Ministerstwo Spraw Wewnętrznych w Warszawie [1944] 1954-1990, Materiały operacyjne, 0192/456, Józef Leszczyński; Franciszek Demel.

${ }^{8}$ K. Polechoński, Kazimierz Sosnkowski jako pisarz, tłumacz i mówca [w:] K. Sosnkowski, Wybór pism, oprac. J. Kirszak, Wrocław 2009, s. XCVII. 
nie przyniosły powodzenia. Nie mogąc wykluczyć, że pułkownik w ogóle nie sporządził kopii swego pisma, decyduję się teraz - po kilkunastu latach „od odkrycia” - ogłosić jedynie list generała.

W prezentowanym dokumencie Sosnkowski, wykazując najwyższy kunszt epistolograficzny, przedstawił wnikliwą ocenę bieżącej sytuacji międzynarodowej. Chociaż pomylił się, sądząc że nowa wojna wybuchnie za kilka - kilkanaście lat, to trafnie przewidział szereg wydarzeń i procesów społeczno-politycznych bliższej i dalszej przyszłości. Przykładowo, wieszczył definitywne rozwiązanie Polskich Sił Zbrojnych na Zachodzie czy finisz akcji Stanisława Mikołajczyka et consortes w podporządkowanej Józefowi Stalinowi Polsce, utratę kolonii przez Wielką Brytanię czy stałą ekspansję imperializmu rosyjskiego. Ukazał też kulisy i skutki usunięcia go ze stanowiska Naczelnego Wodza, które proces likwidacji wojska na obczyźnie znacznie przyśpieszyły, a co najważniejsze, zaprzepaściły możliwość lepszego zabezpieczenia bytu żołnierzy na emigracji oraz funduszy na zorganizowaną robotę niepodległościową w wolnym świecie. Wypowiedź generała cechuje trzeźwość oceny działalności politycznej najwyższych polskich władz państwowych i wojskowych w ostatnich miesiącach II wojny światowej, drobiazgowo analizuje on zakulisowe rozgrywki personalne, które doprowadziły np. do odwołania gen. dyw. Władysława Andersa z funkcji p.o. Naczelnego Wodza na rzecz gen. dyw. Tadeusza Bora-Komorowskiego.

Reasumując, dokument ten stanowi ciekawy materiał dla badaczy początków powojennej emigracji, procesu likwidacji Polskich Sił Zbrojnych, jest wreszcie cennym przyczynkiem dla biografów Kazimierza Sosnkowskiego, chcących odtworzyć początki egzystencji generała w Nowym Świecie.

Przygotowując niniejszą edycję uwspółcześniłem ortografię, niekiedy poprawiłem interpunkcję. Wszystkie podkreślenia w tekście pochodzą od gen. Sosnkowskiego.

W przypisach podałem notki biograficzne występujących w liście osób, z wyjątkiem powszechnie znanych światowych przywódców, takich jak Winston Churchill, Franklin D. Roosevelt, Józef Stalin, Dwight D. Eisenhower czy krajowych jak Władysław Sikorski. Omówiłem też szerzej niektóre poruszone wątki i przetłumaczyłem zwroty obcojęzyczne.

Dokument jest przechowywany w archiwum Instytutu Józefa Piłsudskiego w Ameryce, w Nowym Jorku, w zespole archiwalnym nr 93 generała Kazimierza Sosnkowskiego. W 2003 r. nosił sygnaturę: kol. I, t. 17/1, k. 81-93. 
odpis $^{9}$

Val Des Bois, Quebec

6 sierpnia 1945.

Kochany Panie Pułkowniku,

Uradowałem się szczerze, ujrzawszy list Pański z daty: Santa Sofia 10 czerwca br. Stwierdzam na wstępie, że od chwili opuszczenia Londynu jest to pierwszy znak życia, jaki dociera do mnie od Pana bezpośrednio. Również od Smoleńskiego ${ }^{10}$ nic nie otrzymałem oprócz depeszy imieninowej, która, oczywiście, odpowiedzi nie wymagała. Co tu taić: było mi bardzo przykro, choć przekładałem sam sobie, że nowy klimat, nowe warunki, chęć wytchnienia po długiej mordędze londyńskiej a przede wszystkim absorbująca atmosfera życia na froncie, gdzie człowiek tak chętnie strząsa proch z obuwia swego, - że wszystko to, razem wzięte, tworzy dostateczny zespół czynników, tłumaczących Pańskie milczenie dokładniej i lepiej, aniżeli przypuszczenie, że wyjeżdżał Pan do Włoch z pewnym osadem jak gdyby goryczy i żalu do mnie. U podstaw tego przypuszczenia tkwiła świadomość, że może byłem zbyt wymagającym w stosunku do Pana, że uczyniłem za mało, by swoich najbliższych współpracowników ochronić przed cierniami londyńskiej egzystencji, że nie zdołałem dać Panu należytego pola i wystarczających warunków do pracy. I na próżno powtarzałem sobie, że sam znosiłem ciernie najgorsze, że niezwykłe i ponad miarę ciężkie okoliczności, wśród których przyszło mi pełnić obowiązki Naczelnego Wodza, tłumaczą mnie chyba aż nadto dostatecznie. Znam dobrze stałą swoją wadę: zapatrzony w sprawy zasadnicze, zbyt mało zawsze zwracałem uwagi na zagadnienia życiowe, na zrozumiałe i naturalne potrzeby ludzkiej natury i ludzkiej psychiki, najbardziej choćby ofiarnej, - która słusznie pragnie, aby w życiu blaski i rekompensaty co najmniej równoważyły twardy wysiłek i samozaparcie moralne.

${ }^{9}$ Dopisek odręczny autora.

${ }^{10}$ Marian Józef Smoleński ps. „Kolec”, „Łukasz” (ur. 1894 - zm. 1978) - płk dypl. kaw. (1933), gen. bryg. PSZ (1964). Żołnierz I Kompanii Kadrowej, od 7 VIII 1914 r. w zalążku 1 Pułku Ułanów (tzw. ósmy ułan Beliny), od listopada 1918 r. m.in. w 7 p. uł., szef sztabu 4 Dywizji Kawalerii (DK), dowódca 2 p. uł., od listopada 1938 r. szef Oddziału II SG; w WP we Francji i w PSZ m.in. II zastępca komendanta ZWZ, szef Oddziału VI Sztabu NW, zastępca szefa sztabu NW. Wysłany na front włoski jeszcze w okresie urzędowania gen. Sosnkowskiego jako NW, był od sierpnia 1944 r. do 1947 r. zastępcą dowódcy 3 Dywizji Strzelców Karpackich (DSK); po wojnie pozostał na emigracji w Wlk. Brytanii (m.in. był wieloletnim prezesem Instytutu Józefa Piłsudskiego w Londynie); zginął tragicznie w Londynie potrącony przez samochód. Podczas II wojny światowej należał do ścisłego grona najbliższych wojskowych współpracowników gen. Sosnkowskiego. 
Z prawdziwą ciekawością czytałem o Pańskich wyczynach jako dowódcy brygady. Cieszę się szczerze z Pańskich sukcesów bojowych, o których słuchy docierały do mnie aż tutaj ${ }^{11}$. Tak więc początek wojny i jej koniec spędził Pan w polu. Jest to piękny przyczynek do Pańskiej kariery żołnierskiej oraz podstawa do uzyskania zasłużonego stopnia generalskiego, który - daj Boże - aby jak najrychlej stał się rzeczywistością. Nawiasem mówiąc, w listach swoich do Londynu podnosiłem, że w sytuacji obecnej dobrym pociągnięciem politycznym byłoby $\mathrm{z}$ naszej strony przeprowadzenie awansów w Siłach Zbrojnych, zanim ze strony „aliantów” nastąpią zdecydowane kroki likwidacyjne.

Pański opis stosunków na terenie Włoch jest bardzo interesujący. Żywię stale i niezmiennie dla II-go Korpusu głęboki sentyment żołnierski, który nie maleje, pomimo iż to moje uczucie, jak się zdaje, odwzajemniane jest z biegiem czasu coraz słabiej. Sądzę, iż uwagi i spostrzeżenia Pańskie, dotyczące zmian zachodzących w obliczu duchowym Korpusu, są trafne, a w każdym razie, uznać je muszę za bardzo przekonywujące. Co do mnie, posunę się o krok dalej i rzucę pytanie, czy było rozsądną i przewidującą polityką gromadzenie i wchłanianie uzupełnień ponad ramy organizacyjne, bez uprzedniego załatwienia z Anglikami sprawy rozwinięcia Sił Zbrojnych? W wyniku mamy; - bez należytego ekwiwalentu wojskowego, - rozwodnienie zwartości ideowej szeregów, i to w czasach, gdy ze względów politycznych, jest ona najbardziej potrzebną.

Prawdopodobnie Pan wie i pamięta, że w ostatnich rozmowach z Prezydentem $^{12}$, tuż przed wyjazdem moim $\mathrm{z}$ Londynu ${ }^{13}$, kładłem mu na sercu jako punkty najważniejsze następujące trzy sprawy, jeszcze przeze mnie jako Naczelnego Wodza wdrożone w postaci memoriałów, złożonych władzom brytyjskim:

1/ Rozbudowa Polskich Sił Zbrojnych do składu trzech pełnych korpusów wojsk lądowych, ze wszystkimi formacjami pomocniczymi (tzw. plan „A” z marca 1944 r.).

${ }^{11}$ Pułkownik dypl. Demel odznaczył się w kwietniu 1945 r. w bitwie pod Bolonią, dowodząc 4 Wołyńską Brygadą Piechoty w 5 KDP, za co został odznaczony Krzyżem Srebrnym Orderu Wojennego Virtuti Militari V kl.

${ }^{12}$ Władysław Raczkiewicz (ur. 1885 - zm. 1947) - adwokat, mjr rez. art. WP (1919), prezydent RP. Podczas I wojny światowej w armii rosyjskiej, w 1917 r. współorganizował Naczelny Polski Komitet Wojskowy. W Polsce niepodległej m.in. minister spraw wewnętrznych i marszałek senatu. W 1. 1921-1939 pełnił funkcję wojewody kolejno: nowogródzkiego, wileńskiego, krakowskiego i pomorskiego. Od 30 IX 1939 r. do śmierci 6 VI 1947 r. piastował urząd Prezydenta RP.

${ }^{13}$ Ostatnią rozmowę z prezydentem gen. Sosnkowski miał 9 XI 1944 r., na dwa dni przed opuszczeniem Anglii. Zob. Dziennik czynności Prezydenta RP Władysława Raczkiewicza 1939-1947, t. 2, oprac. J. Piotrowski, Wrocław 2004, s. 389. 
2/ Połączenie Polskich Sił Zbrojnych na jednym kierunku operacyjnym, najlepiej na kierunku Francja - Belgia - Holandia - Niemcy.

3/ Użycie formacji naszych oraz specjalnych oddziałów, tworzonych z deportowanych Polaków na terenie Niemiec do zadań okupacyjnych.

Wszystkie powyższe trzy memoriały uzupełniały się wzajemnie, tworząc jednolitą, organiczną całość. Prezydent przyrzekł mi pilnować tych spraw jak źrenicy oka, a nadto obiecał mi, że jeśli dojdzie do połączenia naszych Sił Zbrojnych, otrzymam nad nimi dowództwo polowe ${ }^{14}$.

Stryjciowi ${ }^{15}$ kazałem czuwać nad rozwojem sytuacji, meldować mi periodycznie o stanie rzeczy, utrzymując $w$ tym celu stały kontakt osobisty z Prezydentem. Byłem też w tym zakresie informowany przez Stryjcia uczciwie i regularnie. Sprawy szły oczywiście bardzo kulawo i właściwie nie ruszały z miejsca: polityka polska Rządu brytyjskiego nie zmieniała się, pomimo zbliżającego się coraz bardziej i pewnego już zwycięstwa nad Niemcami. Wielkie więc było moje zdziwienie, gdy w kilka tygodni po objęciu przez Andersa ${ }^{16}$ obowiązków Naczelnego Wodza zaczęły krążyć pogłoski, że zgoda Anglików na rozbudowę naszych Sił Zbrojnych została uzyskana. Po pewnym czasie w prasie amerykańskiej pojawiły się korespondencje, głoszące urbi et orbi $i^{17}$, że nasze siły lądowe mają być znacznie powiększone. Poda-

${ }^{14} \mathrm{~W}$ ostatniej rozmowie Raczkiewicza z Sosnkowskim przed jego wyjazdem z Anglii, prezydent zakomunikował generałowi, że przewiduje powierzyć mu stanowisko dowódcy sił lądowych; zob. K. Sosnkowski, Materiały Historyczne, oprac. J. Matecki, Londyn 1966, s. 45.

${ }^{15}$ Witold Babiński (ur. 1897 - zm. 1985) - por. rez. art. (1932), kpt. PSZ (1944), dr nauk rolniczych (1923), ekspert przemysłu drzewnego. Od października 1918 r. w Szkole Podchorążych Piechoty w Warszawie, w 1920 r. ppor. i dowódca plutonu 6 Dywizjonu Artylerii Konnej. W 1. 1927-1939 dyrektor Zrzeszenia Związków Właścicieli Lasów. W 1939 r. zmobilizowany do Ośrodka Zapasowego Artylerii Konnej nr 1. W 1. 1940-1944 adiutant do szczególnych zleceń (kontaktów z prezydentem i rządem RP) gen. Sosnkowskiego. W 1. 1946-1948 we Francji, od 1949 r. w Kanadzie, gdzie zmarł. Zwrot „Stryjcio” użyty przez Sosnkowskiego powstał w 1940 r. we Francji, gdy w KG ZWZ (tzw. Biuro generała Sosnkowskiego) w Angers pracowała Wanda Babińska, bratanica Witolda.

${ }^{16}$ Władysław Anders (ur. 1892 - zm. 1970) - gen. bryg. WP (1934), gen. broni PSZ (1954). Podczas I wojny światowej w armii rosyjskiej, od 1917 r. w I Korpusie Polskim na Wsch. (KP), od lipca 1918 r. w Polskiej Sile Zbrojnej, od stycznia do kwietnia 1919 r. szef sztabu Wojsk Wielkopolskich, po czym dowódca 1 p. uł. Wlkp. (późniejszy 15 p. uł.), w 1. 1921-1923 ukończył francuską École Supérieure de Guerre, w l. 1926-1937 dowódca 2 Samodzielnej Brygady Kawalerii (późniejsza Kresowa Brygada Kawalerii - BK), następnie Nowogródzkiej BK, od 28 IX 1939 r. w sowieckich więzieniach, od sierpnia 1941 r. dowódca PSZ w ZSRR, od 1942 r. dowódca Armii Polskiej na Wschodzie, od 1943 r. 2 Korpusu, od 26 II 1945 r. p.o. Naczelnego Wodza w Londynie, w czerwcu tr. powrócił do 2 Korpusu, od listopada 1946 r. Generalny Inspektor Sił Zbrojnych. 4 VIII 1954 r. wypowiedział posłuszeństwo prezydentowi Augustowi Zaleskiemu, w 1. 1954-1970 członek Rady Trzech i Naczelny Wódz.

${ }^{17}$ (łac.) - miastu i światu, do wiadomości powszechnej. 
wano cyfrę 250-300.000 żołnierza. Polacy tutaj skakali z radości, upatrując w tych nowinach dowód zasadniczego zwrotu w sprawach politycznych; kredyt Andersa szedł bardzo w górę. Niestety, nie mogłem podzielać optymizmu rodaków i musiałem przestrzegać ludzi, iż czeka ich nieuchronne, moim zdaniem, rozczarowanie.

Odcyfrować to, co się dzieje naprawdę, nie było rzeczą trudną dla wprawnego i doświadczonego oka. Anders nic nie uzyskał, bo w istniejących warunkach brytyjskiej polityki międzynarodowej nic uzyskać nie mógł poza tym, co było już naszym stanem posiadania (ograniczona rozbudowa II Korpusu $^{18}$, gromadzenie uzupełnień dla starego O. de B. oraz udział 1 Dywizji Pancernej w operacjach na terenie Niemiec).

Skąd więc powstały pogłoski i wiadomości o rzekomych jego sukcesach osiągniętych u Churchill'a i Eisenhower'a? Jak zwykle w podobnych wypadkach bywa, wiele optymistycznych wersji lansowano z polskich źródeł na użytek rynku wewnętrznego, w rozgrywce o stanowisko Naczelnego Wodza. Poza tym jednak, co było o wiele ważniejszym, - wiadomości, rozdmuchiwane w prasie amerykańskiej odsłoniły rychło swoje właściwe prowokatorskie oblicze. Okazało się, że najwięcej i najgłośniej o tym krzyczały pisma, znane ze swych sowietofilskich tendencji. W tym samym czasie tęż samą prasę obiegła wiadomość, że gen. Sosnkowski opuścił Kanadę i jest już na Atlantyku, w drodze do Londynu, gdzie ma objąć stanowisko Premiera Rządu Polskiego, przy czym Wicepremierem, Ministrem Wojny oraz Naczelnym Wodzem będzie mianowany gen. Anders. Wszystko stało się aż nadto jasnym: chodziło o to, aby puszczając $\mathrm{w}$ prasie anglosaskiej prowokacyjne wieści, dać odskocznię rządowi sowieckiemu do interwencji i nacisku w sprawach polskich na Rządy Stanów Zjednoczonych i Wielkiej Brytanii. Przypuszczam zresztą, że Andersowi Anglicy (niemiarodajni) mogli coś niecoś obiecywać, on zaś ze zwykłą sobie naiwnością przyjmował piękne słówka i ogólnikowe frazesy za dobrą monetę. No i „wierzył Anglikom”. A przecież doświadczenie powinno go już było nauczyć ostrożności. Mógł był wspomnieć swój entuzjazm po wizycie Churchill’a na froncie włoskim, mogły mu stanąć przed oczyma niewczesne słowa jego dziwnego listu ${ }^{19}$, wystosowanego

${ }^{18}$ Mowa o formowaniu w 2 Korpusie m.in. trzecich brygad piechoty w 3 DSK i 5 KDP, które rozpoczęto jeszcze przed dymisją Sosnkowskiego. Właśnie dowództwo jednej z tych brygad przypadło płk. Demelowi.

${ }^{19}$ Mowa o liście z 7 IX 1944 r., w którym dowódca 2 Korpusu pisał do NW m.in. tak: „Z wizyty premiera brytyjskiego jesteśmy zadowoleni. Zapewnił mnie wielokrotnie, że W. Brytania, a także Stany Zjednoczone, nigdy Polski nie opuszczą i takowa będzie «championem» w Europie. [...] Mamy całkowitą wiarę w Stany Zjednoczone i Wielką Brytanię [...]”; zob. BZNiO, Papiery Kazimierza Sosnkowskiego, rkps 16558/II, List Władysława Andersa do Naczelnego Wodza z 1 IX 1944 r., b.m., k. 60, 61. List ten i odpowiedź gen. Sosnkowskiego z 14 IX 1944 r., zob. W. Babiński, Przyczynki historyczne do okresu 1939-1945, Londyn 1967, s. 688-693. 
do mnie po rozkazie $\mathrm{Nr} 19^{20}$, mógł był sobie wreszcie uprzytomnić, że podpis brytyjski w sprawie połączenia naszych Sił Zbrojnych został położony najformalniej i najuroczyściej w umowie polsko-angielskiej z lipca $1940 \mathrm{r}^{21}$

Postaram się teraz w formie możliwie treściwej przedstawić Panu mój pogląd na ogólną sytuację polityczną w przekroju dnia dzisiejszego.

W wyniku dokonanej zbrodni, polegającej na przeszachrowaniu naszej niepodległości, Polska stała się kolonią sowiecką i proces jej sowietyzacji może być przerwany jedynie przez nowe wielkie wypadki o skali międzynarodowej. Pan Mikołajczyk ${ }^{22}$ et consortes $^{23}$ spełnili w stu procentach podyktowaną przez obcych rolę listków figowych, okrywających wobec opinii światowej gwałty rosyjskie nad Polską. Alianci „uratowali twarz” i zgodnie z przewidywaniem i ostrzeżeniami moimi sprzed lat paru - stroją zdradę swoją w obłudne argumenty, że to, co się stało, jest wynikiem woli Polaków, aktem zgody i jedności narodowej. Cała prasa anglosaska z małymi wyjątkami nastawiona jest na ton powyższy; propaganda za powrotem do Kraju Sił Zbrojnych, uchodźców i deportowanych trąbi na całego, używając znamiennych twierdzeń: „Polska jest tuż po Rosji najbogatszym i najpotężniejszym krajem w Europie, jeno jej rąk potrzeba do pracy”; albo też, - „demokratyczność i tolerancja rosyjska w Polsce przeszła najśmielsze oczekiwania optymistów”; wreszcie po prostu: „Polacy na terenie Niemiec stali się bandytami rabującymi z bronią w ręku spokojną ludność niemiecką

${ }^{20}$ Mowa o słynnym rozkazie Naczelnego Wodza nr 19 z 1 IX 1944 r., w którym Sosnkowski oskarżył zachodnich sprzymierzeńców o brak dobrej woli wobec Polski i świadome podporządkowanie jej Stalinowi.

${ }^{21}$ Faktycznie umowę tę gen. Sikorski i Churchill podpisali 5 VIII 1940 r. Regulowała ona warunki formowania i użycia Polskich Sił Zbrojnych jako wojska sojuszniczego. Załącznik 2, art. III, pkt 2 brzmiał: „W zasadzie wszystkie polskie jednostki będą użyte tak, żeby tworzyć jedną operacyjną jednostkę na jednym teatrze operacyjnym, pod dowództwem polskiego dowódcy na tym teatrze, lub dowódcy wyznaczonego przez niego" (Polskie Siły Zbrojne w drugiej wojnie światowej, t. II: Kampanie na Obczyźnie, cz. 1, Londyn 1959, s. 228).

${ }^{22}$ Stanisław Mikołajczyk (ur. 1901 - zm. 1966) - działacz ludowy. W 1. 1930-1935 poseł na sejm, wicepremier w 1. 1941-1943, premier od lipca 1943 r. do listopada 1944 r. Wbrew legalnemu rządowi RP uznał postanowienia jałtańskie i w czerwcu 1945 r. wrócił do Polski, został wicepremierem i ministrem rolnictwa Tymczasowego Rządu Jedności Narodowej (TRJN). Jako wicepremier wnioskował o pozbawienie gen. Andersa polskiego obywatelstwa, wyraził zgodę na unieważnienie konkordatu ze Stolicą Apostolską, namawiał polskich żołnierzy z Zachodu do powrotu do Polski, mimo to w kraju stał się symbolem opozycji wobec komunistów; w październiku 1947 r. zagrożony aresztowaniem uciekł z Polski do Stanów Zjednoczonych.

${ }^{23}$ (łac.) - i towarzysze. Mowa tu o tych ministrach gabinetu Mikołajczyka, tj. Stanisławie Kocie, Janie Stańczyku, Władysławie Banaczyku, Karolu Popielu, Ludwiku Grossfeldzie, Henryku Strasburgerze, ks. Zygmuncie Kaczyńskim, którzy uznali postanowienia jałtańskie i w 1945 r. związali się z reżimem Bolesława Bieruta. 
(!) teren Niemiec musi być spiesznie oczyszczony z tych niespokojnych i niepożądanych elementów"!

Cóż będzie dalej?

Jest dla mnie jasnym od dawna, że obecny okres przejściowy musi potrwać czas dłuższy. Nigdy nie wierzyłem, aby jedna wojna mogła przejść bezpośrednio w następną; historia nie zna wojen prewencyjnych, prowadzonych przez ustroje demokratyczne. W świecie anglosaskim rozwija się proces przewlekły, podczas trwania którego odgrywać będą rolę przemożną imponderabilia takie, jak appeasement ${ }^{24}$, chęć uratowania pokoju za wszelką cenę; chęć używania życia po długiej, krwawej i męczącej wojnie; pęd do businessu i zarabiania. Na ołtarzu „pokoju” długo jeszcze będą z cynizmem składane ofiary z cudzej wolności i z cudzych interesów; Anglosasi ciałem i krwią narodów słabszych, państw mniejszych będą „karmić krokodyla”, dopóki złodziejski pysk nie wsunie się dostatecznie głęboko do ich własnej kieszeni, po ich terytoria, ich złoto, ich naftę, po ich bezpośredni stan posiadania. U końca tego okresu widzę wojnę świata anglosaskiego o swoją własną skórę. Dzięki krótkowzrocznej i lękliwej polityce obecnej Anglosasi prawdopodobnie zmierzyć się będą musieli z koalicją kontynentalną, którą Sowiety zmontują pod swoją własną flagą.

Nie ma siły, która by drogą perswazji i przekonywania mogła skłonić politykę i opinię anglosaską do zrozumienia prawd powyższych, - lub też, co jest ściślejszym, - nie ma siły, która by na tej drodze mogła spowodować ze strony Anglosasów akty przewidującej woli, Mundus vult decipi $i^{25}$, - a Pan Stalin może okazać się dostatecznie chytrym, aby dozować swoje dawki w sposób umiejętny, rzucać odpowiednie przynęty, ryby anglosaskie brać na hak i prowadzić je na płytkie wody, skąd łatwiej je będzie wyciągnąć na brzeg i wrzucić do wora.

Co do losów kontynentu europejskiego widzę następujące alternatywy:

a/ albo dojdzie względnie szybko do wojny

b/ albo Europa ulegnie zbolszewizowaniu.

Bodaj tertium non datur ${ }^{26}$.

Jeśli polityka sowiecka będzie dostatecznie umiarkowana, zadowoli się na razie przeżuwaniem rzuconych jej tłustych kęsów bez włażenia Anglosasom na odciski na innych kontynentach, - wówczas Anglia i Ameryka za cenę dodatkowych kilku lub kilkunastu lat względnego spokoju poświęcą z lekkim sercem Europę po to, aby w najgorszych dla siebie warunkach stanąć oko w oko z Rosją do rozprawy o panowanie nad światem lub raczej o swoją własną egzystencję.

\footnotetext{
${ }^{24}$ (ang.) - wyciszenie, zaspokojenie.

25 (łac.) - świat chce być oszukiwanym.

${ }^{26}$ (łac.) - trzeciego wyjścia nie ma.
} 
Na razie Stalin gra bardzo zręcznie, zdradzając dużą znajomość stosunków na Zachodzie i duchowych przywar wielkokapitalistycznych demokracji. Przypuszczam jednak, że wcześniej czy później umiar opuści władców Kremla; że siły przez nich rozpętane popychać ich będą w kierunku Machtopolitik ${ }^{27}$, do kroków nieoględnych; że gołowokrużenje ot uspiecha ${ }^{28}$ okaże się czynnikiem przyspieszającym procesy kryzysowe. Stąd moja hipoteza, iż - najprawdopodobniej - od nowej wojny dzieli nas lat kilka co najwyżej.

Na tle powyższym rozwój wypadków w Kraju może potoczyć się w sposób następujący:

Mikołajczyk et consortes już wykonali część pensum, przewidzianego dla nich przez Sowiety, jednak ich rola daleką jest jeszcze od ukończenia. Jeszcze rząd sowiecki musi otrzymać miliardy amerykańskie; jeszcze przy pomocy Mikołajczyka i jego kliki ujawnić się musi w Polsce wszystko to, co mogłoby poza komunistami stanowić jakąś kierowniczą w sensie politycznym warstwę; jeszcze przy pomocy naszych prosowieckich Quislingów ${ }^{29}$ trzeba ściągnąć z emigracji do Kraju możliwie wiele cywilnych i wojskowych elementów, aby rozładować na gruncie zagranicznym potencjalne ośrodki „polskiej intrygi”. Gdy to wszystko będzie osiągnięte, wówczas w pewnym momencie, pod pierwszym lepszym pozorem, nastąpi drugi akt czystki i likwidacji inteligencji polskiej i to na wielką skalę: grunt do "demokratycznych i wolnych" wyborów w Polsce będzie gotowy. Wówczas żadne, najbystrzejsze choćby oczy na Zachodzie, - ani tym bardziej przymknięte oczy panów ambasadorów Lane'a ${ }^{30}$ i Cavendish Bentinck'a ${ }^{31}$, nie dojrzą już na terenie Kraju nikogo poza entuzjastami najściślejszego związania się z Rosją sowiecką. Obojętnym będzie tedy, jaki los spotka naszych „mężów stanu, odwracających bieg dziejów Polski”. Może staną się oni stuprocentowymi

\footnotetext{
${ }^{27}$ (niem.) - polityka silnej ręki, mocarstwowa.

28 (ros.) - zawrót głowy od sukcesu (powodzenia).
}

${ }^{29}$ Vidkun Quisling (ur. 1887 - zm. 1945) - premier Norwegii z ramienia Niemców, po wojnie osądzony i rozstrzelany. Symbol kolaboracji z okupantem podczas II wojny światowej.

${ }^{30}$ Arthur Bliss Lane (ur. 1894 - zm. 1956) - amerykański polityk, dyplomata. W 1. 1919-1920 sekretarz poselstwa Stanów Zjednoczonych w Polsce, później m.in. ambasador w Nikaragui, na Litwie, Łotwie i w Estonii, od $1944 \mathrm{r}$. ambasador przy rządzie RP w Londynie (prezydent Franklin D. Roosevelt nie wydał zgody na wyjazd do Wlk. Bryt.), a w 1. 1945-1947 przy TRJN w Warszawie (podał się do dymisji w proteście przeciw fałszerstwom wyborczym), współtwórca i przewodniczący (1948-1951) Amerykańskiego Komitetu do Zbadania Zbrodni Katyńskiej.

${ }^{31}$ Victor Cavendish-Bentinck (ur. 1897 - zm. 1990) - brytyjski arystokrata, biznesmen, polityk i dyplomata. Podczas II wojny światowej m.in. przewodniczący Wspólnego Komitetu Wywiadowczego (nie dał wiary raportom przekazanym w sierpniu 1943 r. przez polską ambasadę o dokonywanej przez Niemców zagładzie Żydów), w 1. 1945-1947 ambasador brytyjski w Warszawie. 
komunistami; może, wykorzystani należycie, wyciśnięci jak cytryny, będą wyrzuceni na śmietnik sowiecki, niby bezużyteczne rupiecie; może oberwą po kulce w tył głowy. Jedno wydaje się pewnym, - mianowicie, że Anglia palcem nie ruszy w ich obronie, a Mikołajczyk, ów great polish statesman ${ }^{32}$ nie doczeka się od swych mandatariuszy więcej aktywnego współczucia i pomocy, aniżeli jego prawie imiennik sprzed ćwierć wieku, bliski krewny angielskiej rodziny królewskiej, Car Wszechrosji, Król Polski, Wielki Książę Finlandzki ${ }^{33}$.

Zanim to wszystko się stanie, trzeba przewidywać, że na obczyźnie i w wojsku, i wśród masy uchodźctwa, pod wpływem agitacji, nieszczędzącej różowych bajek o rajskich stosunkach na terenie Kraju, w atmosferze nostalgii i tęsknoty za rodzinami, pod naciskiem prohibicyjnej presji ekonomicznej i szykan administracyjnych, znaczna część Polaków zechce wracać do Polski. Na wojsko działać się będzie metodami zmierzającymi do wewnętrznego rozdarcia szeregów, a naszkicowanymi bardzo znamiennie w Pańskim liście. Tych Polaków, którzy pozostaną poza granicami Kraju, na pewno wystarczyłoby, aby kontynuować pomimo wszelkich trudności polityczną i propagandową pracę na rzecz naszej sprawy. Praca podobna wymaga jednak organizacji i środków materialnych, - a jak się, niestety, zdaje, Rząd nasz nic nie przygotował i nie zabezpieczył zawczasu.

My tutaj, nie wyłączając Posła ${ }^{34}$, bardzo mało lub zgoła nic nie wiemy o planach i zamiarach Rządu. Nieliczne i mało mówiące dyspozycje dotyczące drugorzędnych szczegółów, trudno brać w rachubę. Najważniejsze decyzje o zabezpieczeniu środków finansowych przyszły o pare dni za późno, - stąd w samej Kanadzie przepadły, a raczej zostały zakonserwowane dla sowieciarzy znaczne środki w złocie (przeszło pół miliona dolarów na rachunku Skarbu, poza złotem Banku Polskiego), których uruchomienie i zabezpieczenie było technicznie i prawnie rzeczą prostą i łatwą. Serce doprawdy boli, gdy się widzi taką opieszałość i takie niedołęstwo, które gniewa tym bardziej, że pod względem ogólnopolitycznym nic stanowisku Rządu zarzucić nie można.

\footnotetext{
32 (ang.) - wielki polski mąż stanu.

${ }^{33}$ Mowa o carze Mikołaju II Romanowie, zamordowanym wraz z najbliższą rodziną przez bolszewików w 1918 r.

${ }^{34}$ Wacław Babiński (ur. 1887 - zm. 1957) - dyplomata, dr ekonomii. W 1. 1915-1917 sekretarz prezydenta Warszawy Zdzisława Lubomirskiego, w l. 1917-1918 dyrektor kancelarii Rady Regencyjnej, od 1 XII 1918 r. w służbie dyplomatycznej. W 1. 1929-1931 poseł nadzwyczajny i minister pełnomocny w Belgradzie, od 1931 r. poseł RP w Hadze, od maja 1940 r. do 31 VIII 1944 r. sprawował tę funkcję przy rządzie holenderskim na emigracji w Londynie, w l. 1942-1944 poseł i zastępca sekretarza generalnego MSZ. Od 1 XI 1944 r. do 5 VII 1945 r. poseł nadzwyczajny i minister pełnomocny RP w Kanadzie. Pozostał na emigracji w Kanadzie.
} 
Tak czy inaczej, nie otrzymaliśmy na razie żadnych życiowych, technicznych dyrektyw dla urzędników, funkcjonariuszy państwowych oraz dla wojskowych pozostających poza linią. Brak tych dyrektyw może spowodować dezorientację, a nawet demoralizację wśród ludzi, których postawa, jak dotychczas jest prawie powszechnie jednolitą i właściwą. Nikt nie jest poinformowany czy i kiedy będzie potrzebny do jakiejś roboty publicznej; czy i kiedy nastąpi chwila od której musi liczyć tylko na własne siły i własną przemyślność. W ten sposób dla wojskowych i urzędników wiernych Rządowi, którzy do ostatniej chwili pragną dochować lojalności i dyscypliny mogą powstać gorsze warunki życiowe i upośledzenie w stosunku do tych, co na własną rękę zaczęli „urządzać się” wcześniej, pod hasłem sauve qui peut $^{35}$. Wojskowi tutaj nie wiedzą, jak długo jeszcze będą otrzymywać pobory, a co ważniejsze, czy są to pobory od Rządu Polskiego, czy też jałmużna brytyjska, do której przecież i ze względów politycznych i moralnych należałoby się ustosunkować w jakiś sposób jednolity.

Nie wiemy tutaj, czy Rząd nasz zdaje sobie sprawę, że logika rzeczy prowadzi i wcześniej czy później zapewne doprowadzi do aktu alianckiego albo rozwiązującego Polskie Siły Zbrojne na obczyźnie, albo też przekazującego je po prostu pod władzę i jurysdykcję uznanego niedawno „rządu” warszawskiego. Nie wiemy tutaj, jakie są przewidywania i dyrektywy Londynu $\mathrm{w}$ jednym i drugim wypadku. $\mathrm{W}$ tym stanie rzeczy obawiam się, aby ludzie po prostu nie porozłazili się na wszystkie strony, zwłaszcza ci, którzy pozostając poza zwartymi oddziałami, pozbawieni są zbiorowych ram, regulujących ich postępowanie.

Przechodzę teraz do sprawy przykrej, która - wyznaję szczerze - dotknęła mnie do żywego. Mam na myśli ustęp listu Pańskiego do Stryjcia, gdzie Pan przytacza niedorzeczne plotki jakobym interweniował u Prezydenta w sprawie obsady stanowiska Naczelnego Wodza, za Komorowskim ${ }^{36}$, przeciw Andersowi ${ }^{37}$. Intrygi podobne pozostawiam amatorom i specjalistom,

35 (franc.) - ratuj się kto może.

${ }^{36}$ Tadeusz Komorowski ps. „Bór” (ur. 1895 - zm. 1966) - płk kaw. (1933), gen. dyw. AK (1944). Podczas I wojny światowej w armii austriackiej. Od listopada 1918 r. w WP, m.in. w 1920 r. dowódca 12 p. uł., a w l. 1927-1938 dowódca 9 p. uł. W kampanii polskiej 1939 r. m.in. zastępca dowódcy Kombinowanej BK. Od października 1939 r. w konspiracji. Od lutego 1940 r. kmdt Obszaru ZWZ Kraków, od sierpnia 1941 r. zastępca dowódcy ZWZ/AK, od lipca 1943 r. dowódca AK, od 30 IX 1944 r. Naczelny Wódz. Od 5 X 1944 do 5 V 1945 r. w niewoli niemieckiej, po czym 28 maja tr. objął w Londynie funkcję Naczelnego Wodza, którą piastował do 8 XI 1946 r. W 1. 1947-1949 premier, 1949-1954 członek Rady Politycznej, od 1956 r. członek Rady Trzech.

${ }^{37}$ Nawiązanie do sporu o stanowisko Naczelnego Wodza, do którego doszło w maju 1945 r. po przybyciu do Londynu uwolnionego z niewoli niemieckiej gen. Komorowskiego. Generał Anders - od 26 II 1945 r. p.o. NW - nie dość, że kwestionował kwalifikacje wojskowe Komorowskiego (wedle zgodnych opinii nadawał się on maksymalnie do dowodzenia 
których przecież u nas chyba nie brak. Żałuję, że w swoim czasie na terenie II Korpusu nie brano mnie w obronę tak, jak teraz, - bez żadnej potrzeby, - broni się Andersa przede mną. Do Prezydenta w ogóle nie wysłałem ani jednego listu. Co więcej, stwierdzam lub przypominam, że w sprawie wyboru osoby następcy po mnie w ogóle nie odegrałem żadnej roli aktywnej. Pan Prezydent we wrześniu 1944 r. zakomunikował mi swój wybór, stawiając mnie wobec decyzji już powziętej; ja zaś ze swej strony, nie mogąc nic ujmować osobie Komorowskiego, zwracałem jednak Prezydentowi uwagę na złe strony i komplikacje, związane $\mathrm{z}$ osobą generała, o którym z góry było wiadomym, że znajdzie się lada dzień w niewoli ${ }^{38}$.

To co się stało i co się dzieje dokoła instytucji Naczelnego Wodza jest aż nadto jasnym, Anders przez swoje dwuznaczne lub co najmniej bierne zachowanie się podczas kryzysu wrześniowego podważył tę instytucję i świadomie czy nieświadomie przyłożył rękę do tego, by stała się ona piłką podrzucaną na fluktach polityki wewnętrznej i zewnętrznej ${ }^{39}$. Fala, na którą patrzył obojętnie, lub którą sam, dmuchając popychał, - po prostu wróciła i uderzyła w niego z kolei.

Mam oczywiście żal do Pana, że Pan, zjadłszy przecież beczkę soli ze mną, znając kryzys wrześniowy od strony zakulisowej, podobnie

pułkiem kawalerii), to jeszcze winił go za wywołanie powstania, które uważał za zbrodnię. Szerzej zob. J. Ciechanowski, Spór o naczelne dowództwo pomiędzy gen. W. Andersem i gen. T. Borem-Komorowskim, „Zeszyty Historyczne” (Paryż) 1990, z. 94, s. 55-65.

${ }^{38}$ Generał Bór-Komorowski został mianowany Naczelnym Wodzem 30 IX 1944 r., w czasie dogorywania powstania warszawskiego. Ustępujący gen. Sosnkowski prosił prezydenta, aby ten „dał nowemu NW rozkaz przybycia do Londynu” (W. Babiński, Przyczynki..., s. 461) - nie pozostawiając mu wyboru i ewentualności pójścia do niewoli wraz z powstańcami. Prezydent nie wydał takiego rozkazu i nowo mianowany Naczelny Wódz odszedł 5 X do niemieckiej niewoli. Jego funkcje w zakresie dowodzenia przejął szef Sztabu NW gen. Stanisław Kopański, w zakresie wyszkolenia minister obrony narodowej gen. Marian Kukiel, a sprawy odznaczeniowe prezydent. Był to początek likwidacji stanowiska Naczelnego Wodza i tryumf Stanisława Mikołajczyka, który od dawna dążył do kasacji tego urzędu i całkowitego podporządkowania wojska politykom.

${ }^{39}$ Mowa o wydarzeniach z ostatniej dekady września 1944 r., gdy ważyła się dymisja gen. Sosnkowskiego ze stanowiska NW. Naciskany prezydent Raczkiewicz wahał się z obawy na reakcję wojska, które - jak sądził - murem stanie za Sosnkowskim. Tymczasem 28 IX 1944 r. na odprawie wyższych oficerów 2 Korpusu gen. Anders stwierdził, że „Naczelny Wódz nie będzie mógł się utrzymać" (Dziennik czynności gen. Władysława Andersa 1941-1945, oprac. B. Polak, Koszalin 1998, s. 273). Obecny na odprawie płk dypl. Józef Smoleński zanotował taką wypowiedź dowódcy 2 Korpusu: „Nie ma możności przeciwstawić się decyzji Prezydenta, który jest najwyższym zwierzchnikiem Sił Zbrojnych i którego decyzje są zgodne z przysięgą żołnierską honorowaną przez żołnierzy" (Ósmy ułan Beliny. Generał brygady Józef Marian Smoleński „Kolec” (1894-1978), materiały zebr. M. Smoleński, oprac. G. Nowik, Warszawa 2008, s. 632). Trzeba zauważyć, że gen. Anders świadomie nie udzielił gen. Sosnkowskiemu zdecydowanego poparcia, ponieważ liczył, że to on zostanie NW, na co pośrednio zwraca uwagę także płk Smoleński (zob. ibidem). 
złośliwych plotek nie zdementował od razu i uważał za wskazane sprawdzać je przy pomocy Stryjcia. Przecież Pan wie, że nie bawię się w intrygi personalne, że spory generalskie i waśnie w natłoku Naczelnych Wodzów nic mnie osobiście nie obchodzą, aczkolwiek bolą mnie jako człowieka, Polaka, żołnierza, obywatela.

Jest chyba jasnym, że w Londynie siedzi kupa intrygantów, którzy nawet w tak tragicznej chwili nie znajdują nic lepszego do roboty jak szczuć i różnić wybitniejszych Polaków o znanym nastawieniu ideowym, przy czym robią to dla celów podejrzanych, pour le roi de Russes ${ }^{40}$. Toż siedzą tam jeszcze Koty, Boruty, Zakrzewscy ${ }^{41}$, - żeby nie sięgać głębiej i bliżej czerwo-

${ }^{40}$ (franc.) - dla króla Rosjan.

${ }^{41}$ Mowa o politykach i wyższych wojskowych, którzy jawnie deklarowali wolę podporządkowania się rządowi w Warszawie i już w 1945 r. wrócili do Polski. W tym wypadku wymienieni z nazwiska to: Stanisław Kot (ur. 1885 - zm. 1975) - prof. historii, polityk. Od 1915 r. kierował Biurem Prasowym Departamentu Wojskowego Naczelnego Komitetu Narodowego (od tego czasu blisko związany z Sikorskim). Od 1920 r. prof. Uniwersytetu Jagiellońskiego (w 1933 r. pozbawiony katedry). Od 1933 r. w Stronnictwie Ludowym, w l. 1936-1939 członek Naczelnego Komitetu Wykonawczego Stronnictwa Ludowego. Po kampanii 1939 r. na emigracji, jeden z najbliższych współpracowników gen. Sikorskiego, od grudnia 1939 r. minister bez teki. W 1. 1941-1942 ambasador RP w ZSRR, 1942-1943 minister stanu na Bliskim Wschodzie, 1943-1944 minister informacji. W lipcu 1945 r. powrócił do Polski i z ramienia warszawskiego TRJN był w 1. 1945-1947 ambasadorem w Rzymie. Od 1947 r. ponownie na emigracji; Mieczysław Boruta-Spiechowicz (ur. 1894 - zm. 1985) - gen. bryg. (1936). Podczas I wojny światowej w Legionach Polskich i II KP. Od listopada 1918 r. do stycznia 1919 r. uczestnik obrony Lwowa, po czym wysłany do Armii Polskiej we Francji, gdzie został dowódcą batalionu 3 Pułku Strzelców Polskich (psp), od kwietnia 1919 r. w WP m.in. dowódca 4 psp, w l. 1922-1926 dowódca 32 pp i 71 pp, 1926-1928 I oficer sztabu w Generalnym Inspektoracie Sił Zbrojnych (inspektorat armii gen. dyw. Edwarda Śmigłego-Rydza), 1928-1934 dowódca piechoty dywizyjnej 20 DP, 1934-1939 dowódca 22 Dywizji Piechoty Górskiej, w kampanii polskiej 1939 r. dowódca Grupy Operacyjnej (GO) „Bielsko”, potem GO „Boruta”, od grudnia 1939 r. do sierpnia 1941 r. więzień sowiecki, następnie do marca 1942 r. dowódca 5 Wileńskiej DP w ZSRR. Od października 1942 r. do marca 1943 r. i od sierpnia 1943 r. do 10 III 1945 r. dowódca I Korpusu w Szkocji, następnie w dyspozycji MON. Należał do 11 sygnatariuszy „Apelu do Żołnierzy, Lotników i Marynarzy" (21 VII 1945 r.) nawołujących do powrotu do Polski, sam wrócił 15 grudnia tr. Po krótkiej służbie w ludowym WP został w lipcu 1946 r. na własną prośbę przeniesiony do rezerwy. Uniknął bezpośrednich represji, jednak przez całe życie w PRL był inwigilowany przez komunistyczne służby specjalne; Tadeusz Zakrzewski (ur. 1893 - zm. 1966) - ppłk dypl. piech. (1937). Podczas I wojny światowej w armii rosyjskiej, od $1917 \mathrm{r}$. w I KP. Od 1918 r. w WP, m.in. w l. 1919-1921 w 29 pp, 1925-1927 w Wyższej Szkole Wojennej (WSWoj), następnie w Oddziale I SG, w 1. 1935-1937 szef sztabu 21 Dywizji Piechoty Górskiej, 1937-1940 attaché wojskowy w Bukareszcie. 19 IX 1939 r. oddał się do dyspozycji przybyłego do Bukaresztu gen. Sikorskiego i wypowiedział posłuszeństwo NW marsz. Śmigłemu-Rydzowi i szefowi sztabu NW gen. Wacławowi Stachiewiczowi. Od 1940 r. w PSZ na Bliskim Wsch., m.in. dowódca kompanii Legii Oficerskiej. W listopadzie 1943 r. zgłosił się ochotniczo do służby w AK, jednakże kurs „cichociemnych” ukończył z wynikiem niedostatecznym (zaliczywszy kurs spadochronowy, niedostateczną ocenę otrzymał na kursie walki konspiracyjnej) i do kraju nie został zrzucony. Wiosną 1945 r. zaakceptował układ 
nych ołtarzy. W otoczeniu Prezydenta nie ma ludzi złej woli, ale głuptasów i pospolitych złośliwców na pewno nie brakuje. Wszystko to są rzeczy znane, zrozumiałe i można by nad nimi przejść do porządku dziennego ze wzruszeniem ramion. Ale żeby Siła-Nowicki ${ }^{42}$ zbierał w Londynie podejrzane plotki i kolportował je na terenie Korpusu, zaś Demel musiał je sprawdzać u źródła, gdyż „wiadomość ta zrobiła w Korpusie najgorsze wrażenie”, - nie, to już doprawdy zbyt wiele. - C'est plus fort que moi ${ }^{43}$.

Sądzę, iż dla każdego, kto choć trochę zna stosunki londyńskie, nie było rzeczą trudną odtworzyć przebieg wypadków.

Prezydent w ostatniej rozgrywce wybrał Komorowskiego prawdopodobnie dlatego, że był on już mianowany Naczelnym Wodzem; cofnięcie nominacji, dokonanej w porozumieniu $\mathrm{z}$ socjalistami, było widocznie politycznie trudne, nie mówiąc już o tym, że stanowiłoby oczywisty afront w stosunku do Komorowskiego. Komorowski jest człowiekiem bliskim Arciszewskiemu ${ }^{44}$ ze względu na powiązania krajowe. Kwapiński ${ }^{45}$ notorycznie nie cierpi Andersa, prezydent jest całkowicie w ręku socjalistów, powolny wobec nich jak dziecko. Czy wreszcie u źródła dymisji Andersa nie było mniej lub bardziej

jałtański, wystąpił z PSZ i w listopadzie 1945 r. wrócił do Polski. Aresztowany w grudniu 1948 r. został poddany brutalnemu śledztwu, na wolność wyszedł w 1955 r.

${ }^{42}$ Danych nie ustaliłem. Niewykluczone, że Sosnkowski popełnił tzw. czeski błąd, wynikający z podobnego brzmienia nazwiska Siła-Nowicki z Nowina-Sawicki. W takim wypadku mogłoby chodzić o płk. dypl. Witolda Nowinę-Sawickiego - dowódcę 6 Lwowskiej Brygady Piechoty z 5 KDP, pod warunkiem że po bitwie o Bolonię Sawicki był krótko w Londynie.

${ }^{43}$ (franc.) - nic na to nie poradzę.

${ }^{44}$ Tomasz Arciszewski (ur. 1877 - zm. 1955) - robotnik, polityk. Od 1896 r. w Polskiej Partii Socjalistycznej (PPS), w 1. 1901-1903 więzień rosyjski, w 1905 r. współorganizował Organizację Bojową PPS, od 1908 r. w Związku Walki Czynnej, od sierpnia 1914 r. w 1 Pułku Legionów Polskich. W 1915 r. skierowany do prac politycznych, od 7 XI 1918 r. minister pracy i opieki społecznej w tzw. rządzie lubelskim, następnie minister poczt i telegrafów (17 XI 1918-16 I 1919 r.), w 1920 r. organizował Robotniczy Komitet Obrony Niepodległości, w 1. 1919-1935 poseł na sejm, członek naczelnych władz PPS, we wrześniu 1939 r. współorganizował Robotnicze Bataliony Obrony Warszawy, od października tr. przewodniczący konspiracyjnej PPS-Wolność Równość Niepodległość, w lipcu 1944 r. odleciał samolotem do Londynu (operacja „Most” III), od 7 VIII 1944 r. następca prezydenta RP, od 29 XI tr. premier i minister pracy i opieki społecznej, w czerwcu 1947 r. zgłosił dymisję rządu, od 1954 r. w Radzie Trzech.

${ }^{45}$ Jan Kwapiński, właśc. Piotr Chałupka (ur. 1885 - zm. 1964) - polityk. Od 1901 r. w PPS, uczestnik rewolucji 1905 r., w l. 1907-1917 więzień rosyjski, w l. 1920-1939 członek Centralnego Komitetu Wykonawczego PPS, w 1. 1922-1930 poseł na Sejm RP, w 1939 r. prezydent Łodzi, po ewakuacji na Kresy aresztowany przez NKWD i wywieziony w głąb ZSRR, od 1941 r. delegat Ambasady RP w ZSRR na Taszkient, od 1942 r. w Wlk. Bryt., w rządzie Sikorskiego minister przemysłu i handlu, w rządzie Mikołajczyka wicepremier i minister przemysłu, handlu i żeglugi, w rządzie Arciszewskiego dodatkowo kierownik ministerstwa skarbu, po wojnie m.in. członek Centralnego Komitetu Zagranicznego PPS w Londynie. 
podświadomych rozumowań, że osoba Komorowskiego pozwala na łatwiejszą jazdę po szynach polityki międzynarodowej, - il reste à voir ${ }^{46}$; trudno jednak nie pamiętać, że czynnik ten na pewno grał decydującą rolę, gdy Prezydent sprzedawał moją głowę ${ }^{47}$.

Pozwoli Pan, Kochany Panie Pułkowniku, że powrócę na chwil kilka do prawa powracającej fali, o którym pisałem powyżej. Przypominam Panu, że na mój rozkaz $\mathrm{Nr} 19$ który został wykorzystany jako pretekst udzielenia mi dymisji, Anders niezwłocznie zareagował listem do mnie, wyrażającym krytykę rozkazu i wiarę w aliantów. Przypominam Panu, że gdy rząd Mikołajczyka ogłosił publiczną enuncjację, jakobym rozkazem swoim „naruszył godność Narodu Polskiego"ม", generalicja i wyżsi wojskowi głucho milczeli. W tej to właśnie chwili wyżsi dowódcy wydali Siły Zbrojne na łup polityków i stronnictw. Dymisja moja dokonana pod naciskiem Stalina, rządu brytyjskiego, Mikołajczyka, ludowców i... socjalistów wywołała kilka zdawkowych depesz do mnie od kilku generałów i starszych oficerów (nie od Andersa!), na ogół jednak pokryto ją rychło niepamięcią. Gdy Prezydent rozparcelował instytucję Naczelnego Wodza pomiędzy siedem instancji, wyżsi dowódcy znów wygodnie milczeli. Jakżeż więc po tym wszystkim dziwić się można, że instytucja Naczelnego Wodza, zamiast być wykładnikiem i personifikacją postawy ideowej wojska, stała się piłką nożną, którą pierwszy lepszy wypadek kopie ze złośliwością i większą jeszcze głupotą. Rzuca Pan w swoim liście retoryczne pytanie: „czyżby naprawdę niektórzy Panowie w Londynie chcieli takiego wojska, któremu jest obojętne kogo ma za Naczelnego Wodza? - przecież to byłoby potworne i bezdennie głupie”.

A jednak tak jest, Panie Pułkowniku: chcą tego bodaj wszyscy politycy, nie wyłączając socjalistów; a „potworność i bezdenna głupota” jest polską rzeczywistością. Dodajmy tylko, dla całości obrazu, że owa rzeczywistość zrodziła się wśród milczenia i obojętności wojska, a nawet przy częściowym współdziałaniu ze strony niektórych wyższych dowódców. Wojsko swoją

${ }^{46}$ (franc.) - okaże się.

${ }^{47}$ Generał Anders w notatce sporządzonej po rozmowie z prezydentem 26 V 1945 r. napisał, że zarówno prezydent, jak i rząd uważają, iż „ze względu na podniesienie polityczne w świecie prestiżu AK i powstania Warszawy jest niezbędnym, aby obowiązki N.W. pełnił gen. Komorowski”. Cyt. za: J. Ciechanowski, Spór..., s. 63.

${ }^{48}$ Mowa o zgłoszonym na Radzie Ministrów 7 IX 1944 r. wniosku premiera do prezydenta o odwołanie NW. Wniosek był motywowany m.in. tym, że Rozkaz NW nr 19 do AK z 1 IX 1944 r. „we wstępie obraża uczucia narodu polskiego” (Armia Krajowa w dokumentach 1939-1945, t. IV: Lipiec-październik 1944, red. T. Pełczyński et al., Wrocław 1991, s. 390). Podczas głosowania 22 września Rada Ministrów jednomyślnie przyjęła ów wniosek. Wywołało to liczne głosy sprzeciwu, prośby i żądania skierowane do prezydenta RP, żeby nie zwalniał NW pod obce dyktando. Prezydent wahał się, przede wszystkim z obawy na reakcję wojska - zwłaszcza 2 Korpusu. Ostatecznie, nabrawszy przekonania, że gen. Anders nie zareaguje, uległ naciskom i 30 IX 1944 r. zdymisjonował gen. Sosnkowskiego. 
biernością przyczyniło się do tego, że Naczelnych Wodzów można zmieniać jak rękawiczki, za podmuchem takich lub innych oportunizmów politycznych. Została utorowana droga do zmian następnych, zależnych od koniunktur i kombinacji chwili bieżącej. A lista oczekujących w ogonku jest przecież obfita; przecież w swoim czasie Boruta był lansowany przez Mikołajczyka i Kwapińskiego; przecież gama kandydatów obejmuje szeroką skalę odcieni: od Sosnkowskiego poprzez Andersa do Komorowskiego, dalej do Kopańskiego $^{49}$ i Tabora ${ }^{50}$, jeszcze dalej poprzez Borutę prowadzi do Modelskiego ${ }^{51}$, skąd już blisko do... Żymierskiego ${ }^{52}$. Oczywiście, nie znaczy to bynajmniej,

${ }^{49}$ Stanisław Kopański (ur. 1895 - zm. 1976) - płk dypl. art. (1939), gen. dyw. PSZ (1944). Podczas I wojny światowej w armii rosyjskiej, od 1918 r. w WP. W 1. 1927-1929 w École Supérieure de Guerre, następnie w Oddziale III SG. W 1. 1937-1938 dowodził 1 Pułkiem Artylerii Motorowej. W kampanii polskiej 1939 r. szef Oddziału III Sztabu NW. W 1. 1940-1943 dowodził Samodzielną Brygadą Strzelców Karpackich i 3 DSK, 1943-1947 szef Sztabu NW. W 1. 1947-1949 Generalny Inspektor Polskiego Korpusu Przysposobienia i Rozmieszczenia.

${ }^{50}$ Stanisław Tatar ps. „Tabor” (ur. 1895 - zm. 1980) - płk dypl. art. (1939), gen. bryg. AK (1943). Od 1918 r. w WP, m.in. w l. 1929-1932 w WSWoj i École Supérieure de Guerre, następnie wykładowca w WSWoj, od 1938 r. dowódca 3 pal Leg., w kampanii 1939 r. dowódca artylerii 3 DP Leg., następnie w ZWZ/AK, w kwietniu 1944 r. odleciał do Londynu (operacja „Most” I), zastępca szefa Sztabu NW ds. Krajowych, w 1. 1945-1947 dowódca artylerii I Korpusu w Szkocji, w tym czasie współpracował z wywiadem ludowego WP, przekazując archiwa Oddziału VI (Specjalnego) Sztabu NW i ponad $2 \mathrm{mln}$ dolarów z funduszu Oddziału VI, należących faktycznie do Rządu RP na Uchodźstwie, oraz 300 kg złotego skarbu Funduszu Obrony Narodowej. Wezwany w 1949 r. do Warszawy został aresztowany i po brutalnym śledztwie skazany na dożywocie. Więzienie opuścił w kwietniu 1956 r.

${ }^{51}$ Izydor Modelski (ur. 1889 - zm. 1962) - płk dypl. piech. (1923), gen. bryg. PSZ (1940), gen. dyw. ludowego WP (1946). Podczas I wojny światowej w Legionach Polskich, od 1918 r. w WP, m.in. w 1920 r. dowódca 79 pp, w l. 1922-1923 na kursie doszkolenia WSWoj, w l. 1925-1927 dowódca 30 pp, od 1928 r. w st. sp. Od 1 X 1939 r. w służbie czynnej we Francji jako I pomocnik ministra spraw wojskowych, od listopada 1939 r. do lipca 1940 r. II zastępca ministra swojsk., następnie do grudnia 1944 r. II wiceminister ON i gen. do zleceń NW. W lipcu 1945 r. wrócił do Polski i wstąpił do ludowego WP, we wrześniu tr. mianowany zastępcą dowódcy Armii na Zachodzie, a w październiku szefem Misji Wojskowej w Londynie z zadaniem ewakuacji żołnierzy PSZ do kraju. W latach 1946-1948 attaché wojskowy w Waszyngtonie. Odwołany, odmówił powrotu do kraju i osiedlił się w USA. Nawiązał współpracę z Mikołajczykiem. Do końca życia zachował wręcz chorobliwe uprzedzenie do tzw. sanacji, a do gen. Sosnkowskiego w szczególności.

${ }^{52}$ Michał Żymierski (właśc. Łyżwiński, później Żymirski, Żymierski i wreszcie Rola-Żymierski), ps. „Zawisza”, „Rola” (ur. 1890 - zm. 1989) - gen. bryg. (1924; w 1927 r. zdegradowany do stopnia szeregowego), marsz. Polski (1945). Podczas I wojny światowej w Legionach Polskich, m.in. dowódca 2 pp, szef sztabu II Korpusu Polskiego na Wsch. i dowódca 2 Pułku Strzelców w 4 Dywizji Strzelców gen. Żeligowskiego, w WP m.in. dowódca 2 DP Leg., w 1. 1921-1923 w École Supérieure de Guerre, 1924-1926 zastępca szefa Administracji Armii. W 1926 r. aresztowany za malwersacje finansowe (kontrakt na zakup masek pgaz.), został skazany prawomocnym wyrokiem na pięć lat więzienia, zdegradowany i pozbawiony odznaczeń. Po wyjściu z więzienia w 1931 r. wyjechał do Francji, gdzie został zwerbowany przez sowiecki wywiad. Podczas II wojny światowej przebywał w okupowanej Polsce, 
abym przypuszczał choć przez chwilę, że Prezydent i Arciszewski grać będą na całej tej klawiaturze. Chodzi o co innego, mianowicie o to, że ważne imponderabilia połamano, otwarto na oścież wrota możliwości dokonywania zmian koniunkturalnych bez moralnego sprzeciwu wojska, uczyniono stanowisko Naczelnego Wodza i personalia Armii rekwizytami rozgrywek partyjnych. Mikołajczyk, Kot, Modelski wiedzieli doskonale, o co im chodzi; socjaliści przykładali ręki ze względów doktrynalnych; Prezydent pływał na wzburzonych falach jak kwiat lotosu; spory zastęp wyższych dowódców poszukiwał karier lub dokonywał porachunków osobistych.

Oto jak powstała rzeczywistość, której potencjalne niebezpieczeństwa uprzytomnimy sobie najlepiej, przypuściwszy na chwilę, że miejsce Arciszewskiego zajmuje socjalista innego pokroju.

Pyta się Pan, kochany Pułkowniku, co się dzieje ze mną? Oto w skrócie historia dni moich od chwili opuszczenia Anglii.

Po trzytygodniowej burzliwej przeprawie przez Atlantyk na małej polskiej skorupie, wylądowałem pewnego dnia grudniowego w Nowym Yorku ${ }^{53}$, gdzie spędziłem dwa tygodnie, należące do najbardziej pracowitych w moim życiu. Odbywałem setki rozmów oraz parę zebrań w zespołach, obejmujących wszystkie bodaj kierunki i odcienie Polonii amerykańskiej, oczywiście za wyjątkiem zadeklarowanych lubliniaków. Na zewnątrz występować nie mogłem, gdyż p. ambasador Ciechanowski ${ }^{54}$ bez mojej wiedzy sprzedał mnie Departamentowi Stanu, uzyskując dla mnie prawo wylądowania i tranzytu przez Stany Zjednoczone w zamian za złożone przezeń zobowiązanie, że powstrzymam się od wszelkich wystąpień publicznych.

W Kanadzie objechałem wszystkie ważniejsze skupienia polskie od Atlantyku do Pacyfiku, a więc: Montreal, Toronto, Ottawę, Winnipeg, Edmonton, Calgary, Vancouver itd. Odbyłem wiele konferencji, wygłosiłem masę przemówień publicznych. Nie chwaląc się, mogę powiedzieć, że praca moja przyczyniła się do tego, iż Polonia amerykańska jak i kanadyjska murem stanęła przy Rządzie legalnym, na stanowisku nieprzejednanej obrony praw

od 1943 r. był doradcą Sztabu Głównego Gwardii Ludowej, od 1 I 1944 r. dowódcą Armii Ludowej i od 21 VII 1944 r. Naczelnym Dowódcą Odrodzonego WP, w 1. 1944-1949 kierownik i minister obrony narodowej. Odpowiedzialny za komunizację kraju i likwidację podziemia niepodległościowego (osobiście zatwierdził około 100 wyroków śmierci).

${ }^{53}$ Generał Sosnkowski odpłynął z Liverpoolu 11 XI 1944 r. na pokładzie m/s „Stalowa Wola”. Statek wyruszył samotnie i dla zwiększenia bezpieczeństwa płynął zygzakami, przez co podróż trwała prawie cztery tygodnie. Do Nowego Jorku zawinął 6 grudnia.

${ }^{54}$ Jan Ciechanowski (ur. 1887 - zm. 1973) - dyplomata, ekonomista. W 1919 r. szef sekretariatu premiera Ignacego Paderewskiego na konferencji pokojowej w Paryżu, w 1. 19191925 radca ambasady w Londynie, 1925-1929 minister pełnomocny i poseł nadzwyczajny w Waszyngtonie. Podczas II wojny światowej początkowo sekretarz generalny MSZ, a w 1. 1941-1945 ambasador RP w Waszyngtonie. W imieniu Polski podpisał Deklarację Narodów Zjednoczonych. Pozostał na emigracji w Stanach Zjednoczonych. 
Polski, Jej całości i niepodległości. Miejmy nadzieję, że ten stan rzeczy okaże się trwałym, - chociaż nie brak tutaj ludowców spod znaku Mikołajczyka.

Działalność moja ściągnęła na mnie gromy ze strony komunistycznych, prokomunistycznych, ukraińskich, prolubelskich itd. elementów w Ameryce i w Kanadzie. Wściekła i prowokacyjna agitacja skierowana przeciw mojej osobie nie ustaje ani na chwilę. W prasie i na zebraniach żąda się wyrzucenia mnie z Kanady, niewpuszczania do Stanów Zjednoczonych, oddania pod sąd jako zbrodniarza wojennego, składa się w tym sensie publiczne memoriały do rządów kanadyjskiego i amerykańskiego. Już w styczniu tutejszy Foreign Office interweniował u Posła Babińskiego, żądając bym zaprzestał rozjazdów i wystąpień publicznych. Oczywiście nie zastosowałem się do tych żądań, ale za to nie jestem pewien, czy pod naciskiem przedstawicieli „rządu” warszawskiego, którzy zjawią się tutaj lada chwila, władze miejscowe nie zechcą wyprosić mnie jako niepożądanego cudzoziemca.

Złośliwe złamanie nogi w kostce przykuło mnie do szpitalnego łóżka na kilka tygodni. Dwa miesiące musiałem chodzić, dźwigając na nodze kilka kilogramów gipsu. W maju zdjęto mi gips: kości zrosły się najzupełniej prawidłowo.

W czasie moich objazdów zainicjowałem przestudiowanie „na wszelki wypadek" problematu ewentualnego osadnictwa żołnierzy polskich w Kanadzie. Razem z konsulem generalnym z Montrealu p. Brzezińskim ${ }^{55} \mathrm{zba}-$ daliśmy warunki rolne, klimatyczne, finansowe, prawne itd. Wynik badań ujęty został w formę zwięzłego memorandum, które przez konsula Brzezińskiego przesłane zostało Rządowi w Londynie. Choć upłynął już od tego czasu szereg długich miesięcy reakcji dotychczas nie ma żadnej. Do listu tego dołączam odpis memorandum, jako materiał informacyjny, który, być może, Pana zainteresuje ${ }^{56}$.

Od połowy czerwca siedzę z żoną i dziećmi w małej wiosce, położonej o sto kilometrów na północ od Ottawy, o pięćdziesiąt kilometrów od stacji kolejowej. Ślicznie jest tutaj: lasy, wzgórza, piękna rzeka i malownicze jeziora. Warunki niesłychanie prymitywne. Mieszkamy w tzw. campie, czyli

${ }^{55}$ Tadeusz Brzeziński (ur. 1896 - zm. 1990) - dyplomata, dr praw i nauk politycznych, por. rez. art. WP (1919). W 1. 1928-1931 konsul generalny w Lille, 1931-1935 w Lipsku, 1936-1937 w Charkowie, 1938-1945 w Montrealu, w l. 1952-1962 prezes Kongresu Polonii Kanadyjskiej. Ojciec prof. Zbigniewa Brzezińskiego (ur. 1928 - zm. 2017).

${ }^{56} \mathrm{~W}$ teczce $\mathrm{z}$ odpisem niniejszego listu nie ma wspomnianego memorandum. Nie odnalazłem go również w innych materiałach Sosnkowskiego w Instytucie Józefa Piłsudskiego w Nowym Jorku i Zakładzie Narodowym im. Ossolińskich we Wrocławiu; tak samo w rozproszonej w Londynie pokaźnej spuściźnie Franciszka Demela, który posiada swoje kolekcje w IPMS, Studium Polski Podziemnej i Instytucie Józefa Piłsudskiego. Również kwerenda w zespole MSZ, w aktach dotyczących placówek kanadyjskich (IPMS, sygn. A.11.E.), nie przyniosła efektu. Być może ten niewątpliwie ciekawy dokument tkwi gdzieś w innych papierach rządowych, a odnalezienie go będzie raczej dziełem przypadku. 
zwykłym drewnianym baraku, przedzielonym wewnątrz deskami na cztery kojce. Elektryczności nie ma, o wannie ani mowy; kuchenka z dziurawych desek sklecona byle jak, zaopatrzona w dymiący wściekle piecyk żelazny, tak ciasna, że jednej osobie trudno jest w niej się obrócić. Ale ponieważ pogodę mamy ciepłą i słoneczną, piękną przyrodę oraz mnóstwo ryb, które można łowić wszędzie gdzie dusza zapragnie, przeto czujemy się znośnie, uważając zresztą pobyt tutaj za prawdziwą zaprawę do życia chłopskiego czy też proletariackiego. Ja dużo czytam i piszę, daję chłopcom lekcje matematyki, wyjeżdżam od czasu do czasu do Ottawy i Montrealu. Żona zapracowana po uszy: oczywiście sama sprząta, gotuje, pierze poza tym uczy chłopców polskiego itd.

Przepraszam Pana bardzo za tę dygresję w dziedziny osobiste i wracam czym prędzej do spraw ogólnego znaczenia.

W zakończeniu Swego listu do Stryjcia pisze Pan, iż niedobrze postępuję przeciągając swój pobyt poza Anglią, że powinienem siedzieć w Londynie i pilnować „polskiego bałaganu”. W odpowiedzi przytaczam wymianę depesz z Prezydentem:

Moja depesza z 15-go stycznia 1945.

„Am [sic!] at your disposal at any moment if need arises. If not please prolong my leave for another six weeks.

General Sosnkowski" ${ }^{\prime 2}$.

Prezydent do mnie, Londyn 18-go stycznia 1945.

„Agree to prolong your leave as stated your cablogram. With my fondest regards.

Władysław Raczkiewicz" ${ }^{58}$.

Moja depesza z dnia 25-lutego 1945.

„Released from hospital I have to wear plaster cast from four to six weeks. Please remember in these difficult times I am at your disposal. I could even leave in plaster if you think my presence in Britain of any use. Accept my best thoughts.

General Sosnkowski" ${ }^{59}$.

${ }^{57}$ Jestem do dyspozycji w każdej chwili, jeśli zajdzie taka potrzeba. Jeśli nie proszę przedłużyć mój urlop o kolejne sześć tygodni. Generał Sosnkowski.

${ }^{58}$ Zgadzam się przedłużyć urlop, jak podano w telegramie. Z poważaniem. Władysław Raczkiewicz.

${ }^{59}$ Wyszedłem ze szpitala, muszę nosić gips od czterech do sześciu tygodni. Proszę pamiętać, że w tych trudnych czasach jestem do Pana dyspozycji. Mógłbym wyjechać nawet w gipsie, jeśli Pan sądzi, że moja obecność w Wielkiej Brytanii jest przydatna. Proszę przyjąć moje najlepsze myśli. Generał Sosnkowski. 
W odpowiedzi... Depesza imieninowa Prezydenta z daty 3-go marca 1945.

„I send you on behalf of my wife and on my own our best wishes for your anniversary. My best thoughts are with you in these difficult times.

Władysław Raczkiewicz"60.

Moja depesza z dnia 20-kwietnta 1945.

„Plaster taken recently off my leg. Please remember I am at your disposal for any task you might consider useful to our country.

General Sosnkowski"61.

Do 1-go maja, a więc terminu, w którym upływał mój urlop, odpowiedzi nie było. Wobec tego, chcąc być jako żołnierz w formalnym porządku, wysyłam depeszę następującą:

1 maja 1945.

„In connection with my telegram of 20th April please prolong my leave until your decision.

General Sosnkowski"62.

W początkach maja podczas podróży po Zachodniej Kanadzie otrzymuję dwie depesze następujące:

3 maja 1945 Londyn.

„Cieszę się z pomyślnego zakończenia kuracji. Doceniając wyrażoną przez Pana Generała gotowość wyjaśniam z Rządem sposób jej wykorzystania. Pozdrawiam serdecznie

Władysław Raczkiewicz".

Londyn, 6-go maja 1945.

"Agree to prolong your leave for three months till first August, kindest regards.

Władysław Raczkiewicz"63.

${ }^{60}$ Przesyłam Panu w imieniu mojej żony i własnym nasze najlepsze życzenia z okazji rocznicy. Moje najlepsze myśli są z Panem w tych trudnych czasach. Władysław Raczkiewicz.

${ }^{61}$ Gips ostatnio zdjęty z nogi. Proszę pamiętać, że jestem do Pana dyspozycji w przypadku każdego zadania, które może Pan uznać za przydatne dla naszego kraju. Generał Sosnkowski.

${ }^{62} \mathrm{~W}$ nawiązaniu do mego telegramu z 20 kwietnia proszę o przedłużenie urlopu do Pana decyzji. Generał Sosnkowski.

${ }^{63}$ Zgadzam się przedłużyć Pana urlop o trzy miesiące do pierwszego sierpnia, pozdrawiam. Władysław Raczkiewicz. 
Moja depesza do Prezydenta z dnia 26-go lipca 1945.

„Being as always at your disposal please prolong my leave if have not any task for me. Best wishes and regards.

General Sosnkowski" ${ }^{\prime 6}$.

Prezydent do mnie, Londyn, 2-go sierpnia 1945.

„Accepted prolong your leave till first November. My best regards.

Władysław Raczkiewicz"65.

Jak więc Pan widzi, Panie Pułkowniku, - dziad stale przemawiał do obrazu, lecz obraz doń nie przemówił ani słowa. Zwracam szczególną uwagę Pańską na zespół depesz z dnia 20-go kwietnia, 1-go maja, 3-go maja i 6-go maja: Trick z datami jest chyba wyraźny, najznamienniejszym jest jednak fakt, że Prezydent udziela mi urlopu, [o] który nie prosiłem. Chyba nie można było powiedzieć w sposób bardziej dobitny: „siedź Pan cicho gdzie jesteś, - ani Rząd ani ja nie życzymy sobie mieć Pana tutaj”.

Zachodzę doprawdy w głowę, czym tłumaczyć sobie należy ten stosunek do mojej osoby, skoro i Prezydent i Arciszewski stali się w polityce wewnętrznej i zewnętrznej wykonawcami mojego programu? ${ }^{66} \mathrm{Czy}$ mamy tu do czynienia $z$ małostkowymi względami oraz intrygami personalnymi? Czy też gra tutaj rolę jakaś naiwna zawiść o rejtanowskie historyczne splendory? Czy „sanatorzy, landlordzi i faszyści”, Raczkiewicz i Arciszewski, obawiają się, że osoba moja stanowić mogłaby niebezpieczny i kompromitujący balast dla ich demokratycznej łodzi? Czy liczy się na możliwość ugody i rozejmu z Mikołajczykiem? Czy też pewne tajne związki i anonimowe ośrodki, grające wybitną rolę w polityce światowej, poprzez swoje polskie filie i macki sięgające wszędzie, wydały na mnie werdykt, który jest posłusznie wykonywany? Czy chodzi po prostu o pipidowiecki sposób myślenia, który

${ }^{64}$ Będąc jak zawsze do Pana dyspozycji, proszę o przedłużenie urlopu, jeśli nie ma dla mnie żadnego zadania. Najlepsze życzenia i pozdrowienia. Generał Sosnkowski.

${ }^{65}$ Zaakceptowane przedłużenie urlopu do pierwszego listopada. Z wyrazami szacunku. Władysław Raczkiewicz.

${ }^{66}$ Antykapitulancka postawa rządu Arciszewskiego spotkała się z uznaniem grupy niezłomnych działaczy niepodległościowych, np. płk dypl. Ignacy Matuszewski, komentując powołanie 30 XI 1944 r. w Londynie nowego gabinetu, głosił entuzjastycznie: „Po pięciu latach wojny Polacy mają nie tylko rząd legalny, ale rząd polski” (I. Matuszewski, O Polske cała, wielka i wolną. Pisma wybrane, t. 2: 1943-1946, wybór i oprac. S. Cenckiewicz, Warszawa 2019, s. 381). Z kolei gen. Sosnkowski na wieść o oświadczeniu rządu o nieprzyjęciu postanowień jałtańskich w prywatnym liście pisał: „W tej chwili przeczytałem treść wywiadu Arciszewskiego udzielonego przedstawicielom prasy. Brawo, żałuję że nie mogę go w tej chwili uściskać. Oby kochany, stary Arcisz trzymał tak dalej!” (IJPA, Archiwum generała Kazimierza Sosnkowskiego, kol. I, t. 17/1, List Kazimierza Sosnkowskiego do Jana Jawicza i Witolda Babińskiego, Montreal 17 II 1945 r., k. 132). 
na gruzach Kraju i w obliczu tragedii narodowej uważa za rzecz najważniejszą realizację umiłowanej doktryny o zneutralizowaniu i ucięciu wpływu wojska na politykę?

Jakaś z powyższych hipotez musi stanowić klucz do zagadki, która doprawdy nie wiem, ale zdaję sobie sprawę, że sytuacja obecna różni się zupełnie od mego położenia za czasów Sikorskiego, gdy lat parę spędziłem w londyńskim Sulejówku wiedząc, iż moje zadanie polega na tym, aby być chorążym i stróżem pewnego ideowego programu. Dzisiaj pomiędzy mną a Rządem istnieje w zakresie zasadniczych zagadnień naszej polityki zagranicznej zupełna animarum communio ${ }^{67}$. Powrót do Londynu wbrew woli Arciszewskiego i Raczkiewicza, czyli nowy londyński Sulejówek, miałby w warunkach obecnych następujące skutki:

a/ rychłą scysję z Prezydentem na tle jedynej, możliwej wówczas roli mojej - mianowicie roli nieproszonego doradcy.

b/ niemożność wywarcia z ubocza realnego wpływu na „polski bałagan” oraz nieuchronny w tym wypadku, lecz znany mi zarzut ze strony przyjaciól, że „Sosnkowski zawiódł”.

c/ pomiatanie mną i moją godnością osobistą bez żadnego pożytku dla sprawy.

Oto, Panie Pułkowniku, dlaczego postanowiłem, że wrócę do Londynu tylko na wezwanie Prezydenta i Rządu oraz na ściśle określone stanowisko. Prezydent od szeregu miesięcy w licznych rozmowach ze Stryjciem łudzi go rzekomą moją rolą pełnomocnika rządowego na terenie obu Ameryk, - podczas gdy ja wiem od Min. Babińskiego, że od dawna na wypadek katastrofy pełnomocnictwo rządowe na Amerykę Północną zlecono Ciechanowskiemu, a na Amerykę Południową Arciszowi ${ }^{68}$. Czy Pan wie, że po objęciu, funkcji Naczelnego Wodza, Anders depeszował do mnie: „myślą i sercem jestem przy Panu Generale”, ${ }^{69}$ zaś Komorowski słał mi wyrazy „wiernej miłości żołnierskiej” - lecz poza tym żaden z nich nie napisał do mnie ani słówka,

${ }^{67}$ (łac.) - wspólnota ducha (zupełna zgoda).

${ }^{68}$ Franciszek Arciszewski (ur. 1890 - zm. 1969) - płk dypl. sap. (1924), gen. bryg. PSZ (1964). Podczas I wojny światowej w armii austriackiej, dostał się do niewoli włoskiej, a z niej do Armii gen. Józefa Hallera, z którą wrócił do Polski. Od 1919 r. w WP, m.in. w 1920 r. szef sztabu 18 DP, w l. 1925-1926 dowódca 28 pp, od 1926 r. w st. sp. W l. 1930-1935 poseł na Sejm RP. Od października 1939 r. do czerwca 1940 r. szef Gabinetu Wojskowego Prezydenta RP, następnie szef Misji Wojskowej w Kanadzie i USA, a od lipca 1941 do grudnia 1944 r. w Brazylii, następnie do 1946 r. Inspektor do Spraw Zarządu Wojskowego. Pozostał na emigracji w Londynie.

${ }^{69}$ Mowa o depeszy z 28 II 1945 r. wysłanej z Londynu do konsulatu w Montrealu: „dla Pana Generała Broni Sosnkowskiego. W chwili tak ciężkiej dla Ojczyzny obejmując obowiązki Naczelnego Wodza, myślą jestem przy Panu Generale. Jednocześnie przesyłam życzenia szybkiego powrotu do zdrowia. Anders". IPMS, Gabinet Naczelnego Wodza, sygn. A.XII.1./66c, k. 24, [on-line]. 
nie uczynił mi żadnej propozycji służbowej ${ }^{70}$, nie interweniował u Prezydenta w sprawie użycia mojej osoby? Czy Pan pamięta depeszę Komorowskiego do mnie z dnia 30 września? ${ }^{71}$ - i, jeśli tak, to proszę mi wytłumaczyć wszystko, co stało się później i co się dzieje obecnie na naszych szczytach politycznych i wojskowych? De quoi s'agit'il??

Pyta się Pan, Panie Pułkowniku, jakie są moje zamierzenia i plany osobiste? Istnieją wedle mego zdania tylko dwie alternatywy: albo będzie stworzona jakaś praca niepodległościowa pod egidą Rządu i jakieś środki na cel powyższy Rząd w nieznany mi sposób potrafił sobie zabezpieczyć, - albo też, co zdaje się jest smutną rzeczywistością, nic nie przygotowano, mimo wielokrotnych moich sugestii, ostrzeżeń i ponagleń, przesyłanych stąd różnymi drogami, poczynając od stycznia br. Trzeba więc będzie, siłą rzeczy, pomyśleć o zdobyciu na obczyźnie jakiej takiej niezależności, zabezpieczyć najskromniejszy choćby kawałek chleba dla dzieci, - oraz możliwości pracy dla Polski stworzyć sobie samodzielnie, - najlepiej tam, gdzie znajdzie się gros naszych żołnierzy emigrantów.

Los Sił Zbrojnych, to problemat, który gnębi mnie nieustannie. Co się stanie z naszymi chłopakami wobec bezradności Rządu i chaosu, jaki panuje w Londynie? Wedle ostatnich wiadomości stamtąd, przeważa wśród naszych sfer rządowych nastrój apatii i żal do samych siebie, że nic się nie zrobiło,

${ }^{70}$ Sosnkowski, pisząc do Demela, nie wiedział, że w drodze do niego było już od ponad trzech tygodni pismo Naczelnego Wodza gen. dyw. Tadeusza Bora-Komorowskiego z daty 10 VII 1945 r. z prośbą o objęcie przez Sosnkowskiego urzędu Kanclerza Kapituły Orderu Wojennego Virtuti Militari. List ten - w którym Komorowski m.in. pisał: „Proszę Pana Generała o nieodmówienie przyjęcia godności Kanclerza kapituły, gdyż jedynie osoba Pana Generała i jego wysoki autorytet w Polskich Siłach Zbrojnych najlepiej gwarantują utrzymanie powagi tego urzędu" - dotarł do adresata dopiero 19 sierpnia. Sosnkowski odpowiedział, że stanowisko kanclerza przyjmuje. Ostatecznie - z nieudokumentowanych powodów Komorowski wycofał się ze swojej propozycji i Kanclerzem Orderu mianował młodszego stopniem i posiadającego niższą klasę Virtuti Militari gen. dyw. Stanisława Maczka. Być może rolę odegrały tu czynniki dosadnie wyrażone wyżej: „siedź Pan cicho gdzie jesteś [...] nie życzymy sobie mieć Pana tutaj”. Zob. IPMS, mjr Jan Jawicz, sygn. KOL.465/10, Pismo Tadeusza Komorowskiego do Kazimierza Sosnkowskiego z prośbą o objęcie urzędu Kanclerza Kapituły Orderu Wojennego Virtuti Militari, Londyn 10 VII 1945 r., b.p., [odpis]; Depesza gen. Kazimierza Sosnkowskiego potwierdzająca przyjęcie stanowiska kanclerza Orderu Virtuti Militari, Ottawa b.d., b.p.

${ }^{71}$ Mowa o depeszy z 30 IX 1944 r., w której gen. „Bór” - nie wiedząc jeszcze o mianowaniu go Naczelnym Wodzem w miejsce Sosnkowskiego, pisał m.in.: „Dochodzące nas z komunikatów radiowych wiadomości o podjętej kampanii przeciw Naczelnemu Wodzowi napawają nas wielką troską i bólem. [...] Mogę zapewnić Pana Generała o naszym pełnym oddaniu jego osobie jako temu, z którym nas wiążą nie tylko węzły tradycji, ale głębokie zaufanie żołnierskie i wiara w Wodza. Dziś, gdy ważą się losy Polski i nasze, niech te proste żołnierskie słowa będą wyrazem oddania i przywiązania do instytucji i osoby Naczelnego Wodza”. Armia Krajowa..., t. IV, s. 421. Depeszę tę gen. Sosnkowski otrzymał 2 X 1944 r.

72 (franc.) - o co tu chodzi? 
aby umożliwić sobie kontynuowanie jakiej takiej działalności. Co do losu wojska teza rządowa brzmi: Siły Zbrojne pozostają na obczyźnie, zaś ci, co zechcą wracać będą zdemobilizowani. Teza warszawsko-sowiecka opiewa: Siły Zbrojne wracają do Polski, zaś kto wracać nie chce, będzie zdemobilizowany. Niestety, szerzy się wśród wyższych oficerów ideologia, znana nam ze słynnego memoriału pułkownika Zakrzewskiego: „przerzućmy się na stronę Sowietów z rozwiniętymi sztandarami i razem z Rosją zdobywajmy podły świat Zachodu"73.

Jak już pisałem powyżej, logika rzeczy wskazuje, że dojść musi do jednostronnego aktu ze strony aliantów, na mocy którego albo nasze Siły Zbrojne ulegną rozwiązaniu, albo będą przekazane pod władzę i jurysdykcję „rządu warszawskiego". Należy mieć nadzieję, iż w obu wypadkach słowo brytyjskie będzie dotrzymane i żołnierze nasi otrzymają gościnę i swobodę ruchów na obszarze Imperium.

Nie łudzę się bynajmniej, że wcześniej czy później wielu żołnierzy zechce wracać do Kraju. Różne się na to złożą względy, które już wymieniłem poprzednio: tęsknota za rodzinami, listy z Kraju szczere, inspirowane lub wymuszone, propaganda sowiecka i Pana Mikołajczykowa, naciski alianckie i presja ekonomiczna $z$ ich strony. Przed oficerami i żołnierzami, pozostającymi na obczyźnie, stanie zagadnienie bytu materialnego i zachowania choćby ogólnych więzi organizacyjnych oraz wspólnoty ideowej, w oczekiwaniu na lepsze czasy, które przecież nadejść muszą.

Wynikać stąd się zdaje jeden przede wszystkim wniosek: należy skupiać się i osiedlać w zwartej gromadzie. Najwięcej wolnej ziemi oraz możliwości osiedlenia się w skupianiu - $\mathrm{i}$ to $\mathrm{w}$ warunkach zbliżonych pod względem klimatycznym do Polski - posiada Kanada. Opory rządów dominialnych przeciw imigracji mogą być pokonane $\mathrm{w}$ wypadku dobrej woli ze strony rządu brytyjskiego. Mianowanie gubernatorem generalnym Kanady marszałka Alexandra ${ }^{74}$ zdaje się stwarzać pomyślną koniunkturę, oczywiście pod

${ }^{73}$ Zapewne parafraza fragmentu memoriału ppłk. dypl. Zakrzewskiego ze stycznia $1944 \mathrm{r}$. pt. „Pogląd na sytuację polityczną i wnioski”. W opracowaniu tym Zakrzewski przewidując ewentualność zajęcia Europy Środowej przez ZSRR, a później po kilku latach konflikt między Zachodem a Wschodem, w konsekwencji którego „nie pozostaje nam nic innego w tej hipotezie, jak pójść na pozorną lub szczerą współpracę z Sowietami”. Zob. D. Miszewski, Memoriał o podziale stref wplywów w Europie Środkowo-Wschodniej pomiędzy Polskę a Związek Radziecki, napisany przez podpułkownika dyplomowanego Tadeusza Zakrzewskiego, przeznaczony dla premiera Stanisława Mikołajczyka, „Studia z Dziejów Rosji i Europy Środkowo-Wschodniej” 2005, nr 40, s. 285-294. Warto dodać, że gdy dokument ten poufną drogą dotarł do Sosnkowskiego, ten chciał oddać ppłk. Zakrzewskiego pod sąd, czemu kategorycznie sprzeciwił się premier Mikołajczyk. Zob. K. Sosnkowski, Materiały..., s. 196, 197.

${ }^{74}$ Sir Harold Alexander (ur. 1891 - zm. 1969) - brytyjski marszałek polny (1944). Od 1911 r. w Gwardii Irlandzkiej, następnie w Brytyjskim Korpusie Ekspedycyjnym we Francji. Pod koniec I wojny światowej dowódca brygady. Po wojnie służył m.in. w Turcji, Gibraltarze 
warunkiem dostatecznie wczesnej decyzji z naszej strony. Decyzja ta nie jest bynajmniej łatwą - ale pamiętać należy, że taktyka bohaterska, zmierzająca do dobrowolnego pójścia za druty kolczaste nie jest celową w warunkach dzisiejszych, gdy walka o przyszłość Polski przeszła już w stadium długofalowe. Inna rzecz, że postępowanie aliantów, zwłaszcza jeśli będzie ono brutalne, bezwzględne i niemoralne, może wbrew naszej woli zaprowadzić wojsko polskie do obozów koncentracyjnych. Tak czy inaczej, wszystko po prostu krzyczy o to, aby Siły Zbrojne posiadały na czele człowieka stanowczego, znającego stosunki na obczyźnie, doświadczonego politycznie, cieszącego się bezwzględnym zaufaniem i posłuchem ze strony mas żołnierskich. Daj Boże, by Komorowski potrafił sprostać zadaniu!

Kochany Pułkowniku, - tyle spraw i myśli ciśnie się pod pióro, że zdejmuje mnie obawa, czy list ten w ogóle dobiegnie końca. Trudno mi się jednak powstrzymać, aby nie poświęcić kilku zdań wypadkowi dnia, tj. wyborom angielskim.

Skądinąd dojście do władzy labourzystów nie stanowiłoby żadnej nadzwyczajnej niespodzianki: jest bodaj zwyczajem w Wielkiej Brytanii, że premier prowadzący zwycięską wojnę, odsuniętym zostaje od steru rządów po jej zakończeniu. Jest ponadto znanym zjawiskiem, iż po każdym wielkim wstrząsie wojennym, świat skręca i ciągnie na lewo. Uderzającym natomiast jest niebywały rozmiar klęski Churchilla i konserwatystów, który zakrawa na prawdziwy przewrót ${ }^{75}$. Ważne są skutki, jakie klęska ta pociągnie za sobą na szerokiej arenie międzynarodowej. Oceniam je w sposób następujący:

1/ wynik wyborów angielskich wywrze nieunikniony wpływ na nastroje polityczne w krajach Europy, przede wszystkim zaś odbije się na przebiegu wyborów we Francji i we Włoszech.

2/ Polityka zagraniczna nowego rządu brytyjskiego prawdopodobnie kształtować się będzie pod znakiem przywiązania do haseł doktrynalnych, oczywiście z uszczerbkiem dla względów praktycznych i zasad zdrowego rozsądku. Zwalczając imperializm rodzimy ułatwić ona może grę i utorować drogę imperializmowi rosyjskiemu. Przekonamy się o tym rychło, obserwując rozwój sytuacji w takich punktach zapalnych jak Grecja i Turcja, Irak, Egipt i świat arabski, Indie, polityka kolonialna. Nie dziwiłbym się, gdybyśmy wcześniej czy później byli świadkami powolnej dezintegracji Imperium

i Indiach. W 1940 r. dowodził 1 DP we Francji. Od 1942 r. w Birmie, od stycznia 1943 r. dowodził 18 Grupą Armii w Afryce Północnej, następnie 15 Grupą Armii we Włoszech (podlegał mu m.in. polski 2 Korpus). Od 1944 r. głównodowodzący wojsk na obszarze Morza Śródziemnego. W 1. 1946-1952 gubernator Kanady, następnie do 1954 r. minister obrony.

${ }^{75}$ Ogłoszone 26 VII 1945 r. wyniki wyborów powszechnych w Wielkiej Brytanii wskazywały, że laburzyści uzyskali około $61 \%$ mandatów, a konserwatyści około 30\% mandatów, tym samym Partia Pracy po raz pierwszy sformowała jednopartyjny rząd większościowy. 
Brytyjskiego, - niestety, ad usum Kremlini ${ }^{76}$. Należy jednak mieć nadzieję, że instynkt wyborców angielskich powstrzyma niebezpieczne eksperymenty w czasie właściwym, czyli jeszcze nie za późno.

3/ Na razie ostoją starego porządku i „starego świata” stają się... Stany Zjednoczone, - gdzie stosunki socjalne i ekonomiczne nie wróżą jednak stałości.

4/ Wszystkie czynniki powyższe przyśpieszać będą procesy kryzysowe. Dylemat zasadniczy pogłębi się i przybierze zarys taki: albo nowa wojna powszechna, albo świat cały podda się i przerabiać będzie eksperyment sowiecki.

5/ Jeśli chodzi o bezpośredni wpływ wyborów angielskich na sytuację polską to obawiam się, że ich wynik da na razie plusy Stańczykowi ${ }^{77}$, niż Arciszewskiemu. Być może, dokonywane będą nowe próby nacisku na Rząd Polski celem sprowadzenia go z dotychczasowej linii.

W sprawie Sosabowskiego ${ }^{78}$ podzielam najzupełniej Pański punkt widzenia. Analogiczny pogląd wyraziłem w listach do Londynu, przy czym prosiłem Jawicza ${ }^{79}$ i Stryjcia, aby zrobili z tego możliwie szeroki użytek wszędzie tam, gdzie zajdzie potrzeba. Naturalnie, gdybym był jeszcze Naczelnym Wodzem, nie dopuściłbym w żadnym wypadku do zwolnienia Sosabowskiego ${ }^{80}$.

${ }^{76}$ (łac.) - na użytek Kremla.

77 Jan Stańczyk (ur. 1886 - zm. 1953) - robotnik, polityk. W 1. 1904-1907 w PPS w zaborze pruskim, w l. 1922-1930 poseł na sejm, 1925-1939 sekretarz generalny Centralnego Związku Górników. Na emigracji od 30 IX 1939 r. do 24 XI 1944 r. minister pracy i opieki społecznej. Funkcję tę pełnił też w TRJN w Warszawie od 28 VI 1945 r. do 18 VII 1946 r. Działacz PPS, później Polskiej Zjednoczonej Partii Robotniczej.

${ }^{78}$ Stanisław Sosabowski (ur. 1892 - zm. 1967) - płk dypl. piech. (1939), gen. bryg. PSZ (1944). Podczas I wojny światowej w armii austriackiej. Od listopada 1918 r. w WP, m.in. w l. 1922-1923 na kursie doszkolenia WSWoj, 1927-1929 dowódca batalionu 75 pp i zastępca dowódcy 3 Pułku Strzelców Podhalańskich, 1929-1937 wykładowca WSWoj, 1937-1939 dowódca 9 pp Leg. i 21 pp. Od 1940 r. w WP we Francji dowódca piechoty dywizyjnej 1 i 4 DP, w Wlk. Bryt. w 4 Kadrowej BS, od 1941 r. organizator i dowódca 1 Samodzielnej Brygady Spadochronowej (SBS). Od grudnia 1944 r. inspektor jednostek etapowych i wartowniczych. Pozostał na emigracji.

${ }^{79}$ Jan Jawicz (ur. 1897 - zm. 1986) - mjr piech. (1938). Podczas I wojny światowej początkowo w armii rosyjskiej, od końca 1915 r. w I Brygadzie Strzelców Polskich, następnie w I KP, od 1919 r. adiutant gen. Lucjana Żeligowskiego, od 1927 r. nieprzerwanie oficer ordynansowy, adiutant i powiernik gen. Sosnkowskiego. Po wyjeździe Sosnkowskiego w 1944 r. do Kanady pozostał w Londynie, gdzie przez szereg lat zajmował się sprawami generała. W 1982 r. wrócił do Polski.

${ }^{80}$ Generał Sosabowski został zwolniony ze stanowiska dowódcy 1 SBS przez szefa Sztabu NW gen. dyw. Kopańskiego rozkazem z 6 XII 1944 r., na skutek wcześniejszego pisma gen. Fredericka Browninga, w którym dowódca 1 Korpusu Powietrznego proponował usunięcie gen. Sosabowskiego, gdyż ten miał być „niezmiernie trudnym do współpracy”. Faktycznie była to zemsta za krytykę dowództwa brytyjskiego podczas operacji „Market-Garden” 
Myślę, że czas już postawić kropkę i resztę wiadomości i rozważań odłożyć do następnej poczty. Na razie przesyłam Panu serdeczny uścisk dłoni, wyrazy niezmiennej przyjaźni oraz proszę o przekazanie najlepszych moich pozdrowień wszystkim przyjaciołom.

(-) Kazimierz Sosnkowski ${ }^{81}$

P.S. W sprawie przyjazdu Pańskiego w sierpniu do Londynu nie potrzebuję chyba dodawać, że gdybym miał stąd jakiekolwiek możliwości dopomożenia Panu uczyniłbym to natychmiast i z największą gotowością ${ }^{82}$.

Źródło: IJPA, Archiwum generała Kazimierza Sosnkowskiego, kol. I, t. 17/1, k. 81-93, mps, [odpis].

\section{Bibliografia}

\section{Archiwalia}

Biblioteka Zakładu Narodowego im. Ossolińskich

Papiery Kazimierza Sosnkowskiego

Instytut Józefa Piłsudskiego w Ameryce

Archiwum generała Kazimierza Sosnkowskiego

Instytut Polski i Muzeum im. gen. Sikorskiego w Londynie

Gabinet Naczelnego Wodza

Kolekcja nr KOL.193, płk dypl. Franciszek Demel

Kolekcja nr KOL.465, mjr Jan Jawicz

Ministerstwo Spraw Zagranicznych

\section{Dokumenty drukowane}

Armia Krajowa $w$ dokumentach 1939-1945, t. IV: Lipiec-październik 1944, red.

T. Pełczyński, H. Czarnocka, K. A. Bohdanowicz, R. Buczek, M. Fieldorf,

K. Iranek-Osmecki, A. Suchcitz, L. Zachuta, J. Żmigrodzki, Wrocław 1991.

Dziennik czynności gen. Władysława Andersa 1941-1945, oprac. B. Polak, Koszalin 1998.

Dziennik czynności Prezydenta RP Władysława Raczkiewicza 1939-1947, t. 2, oprac. J. Piotrowski, Wrocław 2004.

we wrześniu 1944 r. (bitwa pod Arnhem). Ani gen. Kopański ani prezydent Raczkiewicz, u którego z wnikliwym wyjaśnieniem meldował się gen. Sosabowski, zabiegając o interwencję, nie próbowali bronić swego podkomendnego (szerzej zob. IPMS, Gabinet Naczelnego Wodza, sygn. A.XII.1/81, Sprawa gen. Sosabowskiego, [teczka dostępna on-line]). Sam Sosabowski miał twierdzić, „że więcej zaszkodzili mu Polacy niż Anglicy” (IJPA, Archiwum generała Kazimierza Sosnkowskiego, kol. I, t. 17/1, List Witolda Babińskiego do Kazimierza Sosnkowskiego, Londyn 22 III 1945 r., k. 31).

${ }^{81}$ Podpis odręczny autora.

${ }^{82}$ Nie wiadomo, w jakim celu płk Demel zamierzał latem 1945 r. przyjechać z Włoch do Londynu. 


\section{Opracowania i wspomnienia}

Babiński S., Kazimierz Sosnkowski, myśl-praca-walka, Londyn 1988.

Babiński W., Przyczynki historyczne do okresu 1939-1945, Londyn 1967.

Ciechanowski J., Spór o naczelne dowództwo pomiędzy gen. W. Andersem i gen. T. Borem-Komorowskim, „Zeszyty Historyczne” (Paryż) 1990, z. 94.

Kirszak J., „Karpacka czwórka” o sobie. Generał broni Kazimierz Sosnkowski, podputkownik dypl. Franciszek Demel, inżynier Rajmund Scholz i kapral Alfred Codello - uczestnicy przejścia przez Karpaty na Wegry we wrześniu-październiku 1939 roku - w świetle własnych relacji [w:] Podkarpacki wrzesień. Polityczne i wojskowe aspekty wojny obronnej Polski 1939 r. na Podkarpaciu, red. A. Olejko i P. Korzeniowski, Rzeszów 2010.

Kirszak J., Generał Kazimierz Sosnkowski 1885-1969, Warszawa 2012.

Kirszak J., Nowa biografia generała Kazimierza Sosnkowskiego, „Przegląd Historyczno-Wojskowy” 2011, nr 1 (234).

Kirszak J., Profesorowi Lechowi Wyszczelskiemu w odpowiedzi, „Przegląd Historyczno-Wojskowy” 2011, nr 2 (235).

Kirszak J., Wybrani oficerowie Armii „Karpaty” i ich późniejsze losy w II wojnie światowej [w:] Dzieje Podkarpacia, t. 4, pod red. J. Garncarskiego, Krosno 2000.

Koreś D., Generał Sosnkowski według Wyszczelskiego, „Biuletyn Instytutu Pamięci Narodowej" 2011, nr 1/2.

Matuszewski I., O Polskę cała, wielka i wolną. Pisma wybrane, t. 2: 1943-1946, wybór i opr. S. Cenckiewicz, Warszawa 2019.

Miszewski D., Memoriał o podziale stref wpływów w Europie Środkowo-Wschodniej pomiędzy Polskę a Związek Radziecki, napisany przez podpułkownika dyplomowanego Tadeusza Zakrzewskiego, przeznaczony dla premiera Stanisława Mikołajczyka, „Studia z Dziejów Rosji i Europy Środkowo-Wschodniej" 2005, nr 40.

Ney-Krwawicz M., Biuro Generała Sosnkowskiego. Komenda Główna Związku Walki Zbrojnej we Francji listopad 1939 - czerwiec 1940, Warszawa 1996.

Ósmy ułan Beliny. Generał brygady Józef Marian Smoleński „Kolec” (1894-1978), materiały zebr. M. Smoleński, oprac. G. Nowik, Warszawa 2008.

Pestkowska M., Kazimierz Sosnkowski, Wrocław 1995.

Polechoński K., Kazimierz Sosnkowski jako pisarz, tłumacz i mówca [w:] K. Sosnkowski, Wybór pism, oprac. J. Kirszak, Wrocław 2009.

Polskie Siły Zbrojne w drugiej wojnie światowej, t. II: Kampanie na Obczyźnie, cz. 1, Londyn 1959.

Sokolnicki M., Przedmowa [w:] Kazimierz Sosnkowski o Józefie Piłsudskim, oprac. S. Biegański, Londyn 1961.

Sosnkowski K., Materiały Historyczne, oprac. J. Matecki, Londyn 1966.

Wojewódzki I., Kazimierz Sosnkowski podczas II wojny światowej. Książę niezłomny czy Hamlet w mundurze?, Warszawa 2009.

Wyszczelski L., Generał Kazimierz Sosnkowski, Warszawa 2010. 


\section{STRESZCZENIE}

Jerzy Kirszak, Cóż będzie dalej? Nieznany list gen. broni Kazimierza Sosnkowskiego z roku 1945 o sytuacji międzynarodowej i perspektywach sprawy polskiej

Po udzieleniu dymisji ze stanowiska Naczelnego Wodza gen. Kazimierz Sosnkowski otrzymał urlop i via Nowy Jork udał się do Kanady odwiedzić ewakuowanych tam małoletnich synów. Niezamierzenie Kanada stała się miejscem jego półinternowania. Zza oceanu śledził rozwój sytuacji międzynarodowej, której ocenę przedstawił m.in. w liście do byłego zaufanego podkomendnego płk. Franciszka Demela. Sosnkowski trafnie przewidział szereg wydarzeń i procesów społeczno-politycznych bliższej i dalszej przyszłości. Przykładowo wieszczył rychłe rozwiązanie Polskich Sił Zbrojnych na Zachodzie, finisz akcji Stanisława Mikołajczyka w podporządkowanej Stalinowi Polsce czy stałą ekspansję imperializmu rosyjskiego. Ukazał też kulisy i skutki usunięcia go ze stanowiska NW, przez co proces likwidacji wojska na obczyźnie znacznie przyśpieszył, a także przepadła możliwość lepszego zabezpieczenia bytu żołnierzy na emigracji oraz funduszy na zorganizowaną robotę niepodległościową w wolnym świecie. Wypowiedź generała cechuje trzeźwość oceny działalności politycznej najwyższych polskich władz państwowych i wojskowych w ostatnich miesiącach II wojny światowej, drobiazgowo analizuje zakulisowe rozgrywki personalne, które doprowadziły np. do odwołania gen. Władysława Andersa z funkcji p.o. Naczelnego Wodza na rzecz gen. Tadeusza Bora-Komorowskiego.

Dokument ten stanowi ciekawy materiał dla badaczy początków powojennej emigracji, procesu likwidacji Polskich Sił Zbrojnych, jest wreszcie cennym przyczynkiem dla biografów Kazimierza Sosnkowskiego.

Słowa kluczowe: II wojna światowa, Kazimierz Sosnkowski, Władysław Raczkiewicz, Władysław Anders, Franciszek Demel, Polskie Siły Zbrojne, Naczelny Wódz, emigracja niepodległościowa

\section{SUM M A RY}

\section{Jerzy Kirszak, What lies ahead? General Kazimierz Sosnkowski's unknown Letter from 1945 on the International Situation and Prospects for the Polish Cause}

After his dismissal from the post of Commander-in-Chief, General Kazimierz Sosnkowski was given a leave of absence and via New York he went to Canada to visit his juvenile sons, who were evacuated there. Unintentionally, Canada became a place of his half-internment. From across the ocean he followed the development of the international situation, the assessment of which he presented, among others, in a letter to a former trusted subordinate, Colonel Franciszek Demel. Sosnkowski 
aptly predicted a number of events and socio-political processes of the near and far future. For example, he forecast the imminent disbanding of the Polish Armed Forces in the West, the end of Stanisław Mikołajczyk's activity in Stalin-controlled Poland, or the constant expansion of Russian imperialism. He also showed the backstage and effects of his removal from the post of Commander-in-Chief, which made the process of dismantling the army in exile much quicker, and due to which the opportunities for securing a better existence of soldiers in exile and funds for organized independence activity in the free world were lost. The General's statement presents a clear-headed assessment of the political activity of the highest Polish state and military authorities in the last months of the World War II, and carefully analyzes the behind-the-scenes personal games which led, for example, to the dismissal of General Władysław Anders from the post of Acting Commander-in-Chief in favor of General Tadeusz Bór-Komorowski.

This document is an interesting material for researchers of the beginnings of post-war emigration, the process of dismantling the Polish Armed Forces, and finally makes a valuable contribution to the biographers of Kazimierz Sosnkowski.

Keywords: World War II, Kazimierz Sosnkowski, Władysław Raczkiewicz, Władysław Anders, Franciszek Demel, Polish Armed Forces, Commander-in-Chief, independence emigration

\section{АННОТАЦИЯ}

\section{Ежи Киршак, Что будет дальше? Неизвестное письмо с 1945 г. ген. брони Казимежа Соснковского о международной ситуации и перспективах польского вопроса}

После отставки с поста главнокомандующего польскими вооруженными силами на Западе генерал Казимеж Соснковский получил отпуск и через Нью-Йорк отправился в Канаду, чтобы навестить эвакуированных туда своих несовершеннолетних сыновей. Непреднамеренно Канада стала местом его „полинтернирования”. Он из-за океана следил за международной ситуацией, оценка которой была изложена в том числе и в письме бывшему доверенному подчиненному, полковнику Франчишку Демелю. Соснковский правильно предсказал ряд событий и общественно-политических процессов в ближайшем и отдаленном будущем. Например, он предвидел скорый роспуск ПВС на Западе, окончание действий Станислава Миколайчика в подчиненной Сталину Польше или постоянную экспансию российского империализма. Он также показал закулисье и результаты снятия его с должности главнокомандующего, что значительно ускорило процесс ликвидации войск на Западе, и, кроме того, была потеряна возможность лучшего обеспечения быта солдат в эмиграции и получения средств для организованной работы независимой эмиграции в свободном мире. Высказывания генерала характеризуются трезвостью оценки политической деятельности высших польских государственных 
и военных властей в последние месяцы Второй мировой войны, он тщательно анализирует персональные закулисные игры, которые привели, например, к отстранению генерала Владислава Андерса от исполнения обязанностей Главнокомандующего в пользу генерала Тадеуша Бор-Коморовского.

Это письмо является интересным материалом для исследователей начала послевоенной эмиграции, процесса ликвидации Польских вооруженных сил на Западе, и, кроме того, это ценный материал для биографов Казимежа Соснковского.

Ключевые слова: Вторая мировая война, Казимеж Соснковский, Владислав Рачкевич, Владислав Андерс, Франчишек Демель, Польские вооруженные силы на Западе, Верховный главнокомандующий, независимая эмиграция 